DEPARTMENT OF ECONOMICS, MANAGEMENT AND STATISTICS

UNIVERSITY OF MILAN - BICOCCA

DEMS WORKING PAPER SERIES

Political knowledge and attitudes toward (de)centralization in Europe

Floriana Cerniglia, Laura Pagani

No. 272 - April 2014

Dipartimento di Economia, Metodi Quantitativi e Strategie di Impresa Università degli Studi di Milano - Bicocca http://dems.unimib.it/ 


\title{
Political knowledge and attitudes toward (de)centralization in Europe ${ }^{\S}$
}

\author{
Floriana Cerniglia* and Laura Pagani**
}

April 2014

\begin{abstract}
The allocation of competences between the EU and Member States is one of most burning issues in the history of the European integration. From a theoretical economic perspective, this ongoing process calls into question the theory of fiscal federalism. In this paper, we study empirically the impact of European citizens' knowledge about the EU on their attitudes toward the allocation of competences. We use micro-data from the Eurobarometer survey. We find that more knowledgeable citizens are more willing to favour centralization of competences to the EU in areas where public intervention by individual Member States causes externalities, where scale economies in the provision of public goods are important and where redistributive and stabilization functions have to be pursued.
\end{abstract}

Keywords: European Union, Information, Policy opinions, Political Economy

JEL classification: H7, D8

\footnotetext{
$\S$ We would like to thank Massimo Bordignon, Federico Etro, participants at the 4th Annual Conference on The Political Economy of International Organizations (Zurich, 2011) and participants at the CESifo Economic Studies Conference on Measuring Economic Integration (Munich, 2011) for helpful discussion and comments. A previous version of this paper circulated with the title "Does Political Knowledge Increase Support for Europe? A Cross Country Investigation of the Attitudes of European Citizens” (Cesifo Working Paper no. 3369, 2011).

* Corresponding author. Department of Economics, Università di Milano Bicocca, Piazza dell'Ateneo Nuovo 1, Milan, 20126, Italy. Tel. +39.02.64483061. Fax +39.02.64483085. E-mail address: floriana.cerniglia@unimib.it.

** Department of Economics, Università di Milano Bicocca, Piazza dell'Ateneo Nuovo 1, Milan, 20126, Italy. Tel. +39.02.64483060. Fax +39.02.64483085. E-mail address: laura.pagani@unimib.it.
} 


\section{Introduction}

We analyze the impact of information on the attitudes of European citizens towards the possible distribution of responsibilities between the European Union and Member States. The main motivation of our analysis is twofold. Firstly, the allocation of competences in the EU is one of most burning issue in the history of the European integration because, as the transfers of sovereignty from the Member States to the EU proceeds, the process of European integration is strengthened. From a theoretical economic perspective, this ongoing process calls into question the theory of fiscal federalism.

Secondly, in recent years a popular view on part of the Commission is that the worrying phenomenon of decreasing support to the project of European integration in recent decades can be overcome if the European institutions become more committed to communicating the advantages of the European project. If citizens are more informed about how the EU works, they will be more conscious about the advantages of the policies adopted, and they will thus begin to appreciate the EU more. In this regard, it is useful to recall that back in February 2006 the European Commission adopted a White Paper on a European Communication Policy whose main purpose was to promote actions to inform citizens better and to be more responsive to their concerns. ${ }^{1}$ In the Commission's view, those actions were crucial in raising awareness and creating commitment to the European project. It is important to note that this White Paper followed the main conclusion reached by the Commission the previous year (January 2005) when, after the draft of European Constitution by the European Convention (never adopted after the rejection by a number of Member States) a special Eurobarometer survey on the draft Constitution was commissioned by the Commission. The survey showed to the Commission that the more people knew about the text of the Constitution, the more they were in favour of it. Based on this result, the Commission and other European institutions started to professionalize their communication machinery (see Bijsman and Altides, 2007) and they have stressed their commitment to bring the Union closer to the citizens. $^{2}$ On the other hand, the same literature on European integration had always emphasized that increasing knowledge could be associated with increasing support. For instance, this idea was present in the Gabel path breaking study (1998a) explaining public

\footnotetext{
${ }^{1}$ Commission of the European Communities, (2006). During the press conference announcing the White Paper, the Vice-President of the Commission Margot Walstrom said "Communication is first and foremost a matter of democracy. People have a right to know what the EU does and what it stands for. And they have a right to fully participate in the European project. Communicating Europe is not just a Brussels affair. EU institutions and Member States must work on it together. The European Union has grown up as a political project but has not found a place in people's heart and minds".

${ }^{2}$ Recall that this commitment started for the first time in December 2001 with the Laeken Declaration on the future of the European Union.
} 
support for European Union. However, if a lack of knowledge could potentially increase the gap between EU politics and citizens, to the best of our knowledge there are no studies that have properly investigated whether it is equally true that rendering more information to citizens about the EU and its policies would systematically increase popular support for the European project as such. In this paper, we try to consider this research question using data from the Eurobarometer survey. We investigate citizens' support for integration in specific policy areas and we try to assess the role of citizens' information in shaping preferences for integration.

What we mean by information is actual (or objective) knowledge possessed by European citizens about the functioning of certain European institutions, inferred using a set of true/false questions, available in the Eurobarometer survey, about how the EU works. We refer to this knowledge as political knowledge. Our claim is that a knowledgeable citizen can recall facts about the history of the EU as well as the functioning of the EU institutions. This also means that a knowledgeable citizen know more the nature of the European multilevel system of governance and therefore should be more able to recognizes the potential advantages (or eventually the disadvantages) of sharing national powers with the European Union.

It is possible to address this link between the role of information and citizens' assessment of the most appropriate decision making level bringing together two different strands of studies. The first one refers to the recently growing body of literature which seeks to understand the attitudes of individuals towards various issues such as redistribution (Alesina and FuchsSchundeln, 2007), pension reform (Boeri and Tabellini, 2012), immigration (Facchini and Mayda, 2008) and economic policy issues (Page and Shapiro, 1983; Blinder and Krueger, 2004). In these papers, among the determinants much emphasis has been placed on factors linked to the self-interest of individuals (Facchini and Mayda, 2008). Moreover, quite interestingly, some authors (Blinder and Krueger, 2004; Boeri and Tabellini, 2012) emphasize and include among the determinants the role of information which turns out having a significant effect in shaping these attitudes. From the above-mentioned papers, we have thus borrowed the idea to include the role of information in shaping preferences of European citizens that, in the context of our paper, are the attitudes towards (de)centralization in many policy areas. We also follow a second strand of studies, wedged in the literature on fiscal federalism, that try to: i) assess if the current EU architecture follows the normative principles of optimal task allocation among levels of government (decentralization versus centralization) 
as suggested by the theory; ${ }^{3}$ ii) analyse empirically the attitudes of European citizens toward the allocation of competences between the EU and Member States. Alesina, Angeloni and Schuknecht (2005) and Ahrens et al. (2008) provide only descriptive results; Cerniglia and Pagani (2009) use multivariate analysis to explain Europeans' attitudes in terms of almost exclusively socio-economic determinants; Mazzaferro and Zanardi (2008) try to estimate (using data from the International Social Survey Programme) individual preferences of European citizens for some public goods in order to verify the dominance of centralization over decentralization or vice versa.

In this latter strand of literature, the role of information is completely neglected. So, the first main novelty of our study concerns the role of information, which we include among the variables explaining citizens' assessment of the most appropriate decision-making level. To measure this latter variable, we consider questions that elicit information on citizens' opinion regarding the enhancement of EU involvement in the areas of defence, foreign policy, immigration, monetary policy (the euro), agriculture and fishery policy and regional policy. The reason why we consider these policy areas is that, as said, we follow the theory of fiscal federalism according to which centralization of competences to the European Union should be optimal when public intervention by individual Member States causes externalities on other Member States and where scale economies in the provision of public goods are important. Moreover, this theory also contends that the central government should have the basic responsibility for the macroeconomic stabilization function and for redistribution among local governments. In this paper, we then want to understand if the political knowledge possessed by European citizens has a role in determining preferences toward centralization of the policies above mentioned to the European Union. Our hypothesis is that more informed Europeans are better able to understand the potential benefits deriving from a more efficient allocation of those competencies between the European Union and the Member States.

The analysis is interesting to us since, prima facie, Eurobarometer data show that citizens' preferences about the allocation of these policies between the EU and Member States fit quite well with the argument of fiscal federalism (see Alesina, Angeloni and Schuknecht, 2005 and Cerniglia and Pagani, 2009). In other words, data show that a deeper EU intervention in all these areas is the wish of the majority of European citizens. The only exception is for agriculture and fishery policy: the majority of citizens (52\%) is in favour of a national

\footnotetext{
${ }^{3}$ See Inman and Rubinfeld (1992), Tabellini (2003) and Alesina and Spolaore (2003, chapter 12)
} 
competence. This result is not totally surprising given the current nature of this policy area: benefits are very concentrate on specific groups of citizens.

Building on this background, this paper is one of the first analysis trying to understand to which extent a better information about EU institutions affects individual preferences for (de)centralization. A very recent exception in the political science literature is a paper by Clark and Helling (2012). They analyse the link between information and citizens' support for the EU in specific policy domains and they find a positive relationship for areas involving cross-border political issues. However, a severe shortcoming of this paper is that endogeneity is completely overlooked. Instead, the potential endogeneity of information with respect to attitudes is a key aspect to take into account when estimating the impact of information on attitudes: if knowledge and EU support are jointly determined by underlying factors unobserved in the data (e.g. a generic preference for EU), assuming that political knowledge is strictly exogenous to opinions on EU leads to biased results. We deal with the endogeneity of information in two ways. First, we control for the level of citizens' attachment to the EU. Second, we use an IV approach and we reach identification using a maximum-likelihood seemingly unrelated two-equation probit model with exclusion restrictions.

To sum up, the basic question that we try to answer is: Does more political knowledge increase support for European integration? Our results - also when considering the potential endogeneity of political knowledge with respect to attitudes - confirm the positive effect of political knowledge on support for EU integration; moreover, they highlight other interesting factors related to citizens' opinions about their preferred allocation of competences.

The remainder of the paper is organized as follows. Section 2 explains the theoretical argument underpinning our hypothesis. Section 3 describes the sample, explains how the variables of interest to us - support for European integration and political knowledge - are measured and it also reports descriptive evidence on the relationship between these two variables. Section 4 presents the estimation strategy and discusses some methodological issues; Section 5 shows the results of econometric analysis, including an analysis of the effect of political knowledge on attitudes after the financial crisis. Sections 6 concludes and discusses the policy relevance of our findings.

\section{Theoretical background}

Generally, studies on support for European integration measure it through a very simple question, present in every Eurobarometer survey since the beginning, that is "Generally speaking, do you think your country's membership of the European Union is a good thing, a 
bad thing, neither good nor bad, or dont' know?". This question - very simple to understand for respondents - has then become the standard measure of citizens' support for European integration, or - equally - the standard measure for public Euroscepticism in Europe. ${ }^{4}$ Looking at this measure across time, public support for Europe collapsed in the postMastricht period and it has continued to drop afterwards. In recent years, the most marked increase in Euroscepticism has taken place in the countries most affected by the crisis. ${ }^{5}$

In the literature, the primary theoretical explanation of this measure of citizens' support for European integrations is the "utilitarian" theory: citizens evaluate the integration process in terms of costs and benefits arising from the process of European integration. These costs and benefits may in turn depend on the socioeconomic characteristics of citizens. Gabel (1998a; 1998b) was the first arguing that public support for European integration can be explained by the social-economic position of individuals. ${ }^{6}$ As it will be shown next, also our analysis highlights the importance of socioeconomic determinants, confirming this long lasting theory of citizens' support for European integration.

In this paper, rather than focusing on general support for more or less integration, we investigate support for integration in specific policy areas. We can do that since the specific wave of the Eurobarometer survey that we use - in addition to the standard measure of citizens' support for European integration - contains also more concrete questions asking citizens how they want to distribute policy responsibilities in different specific areas between the European Union and national governments. In our view, and according to other studies (Citrin and Sides, 2004; Hooghe 2003), these set of questions provide a more fine-grained measure of citizens' support for European integration since they capture very well the debate surrounding the process of European integration and eventually its future development as a federation. ${ }^{7}$ From an economic perspective, the allocation of responsibilities among levels of government (i.e. the central government and decentralized, or local, governments) is a classic question in the theory of fiscal federalism spurred by the functional rationale that underlies the well-known Oates' theorem of decentralization (Oates, 1972) that states that centralization

\footnotetext{
${ }^{4}$ See Laconte (2010)

${ }^{5}$ Serricchio et al. (2013)

${ }^{6}$ More precisely, he suggested that persons with more economic, cultural and social capital have more possibility to take advantage of the free market's labour, service and capital. Therefore, they are probably more likely to evaluate European integration as an opportunity. Several empirical studies in the political science literature confirm this utilitarian theory; for a survey see Eichenberg and Dalton (2007). Very recently, the Journal of Common Market Studies (2013, vol 51) has devoted a special issue to the increasing phenomenon of Euroscepticism.

${ }^{7}$ For instance, recall that the allocation of responsibilities between the EU and the Member States has been one of the central arguments in the discussion surrounding the European Convention.
} 
is desirable when there are economies of scale and externalities on other localities that should be internalized. On the other hand, decentralization can be a solution for provision of those public goods where heterogeneity of preference among localities is more likely. Furthermore, this theory contends that the central government should have the basic responsibility for the macroeconomic stabilization function and for income redistribution (Oates, 1999) In other words, only a central macroeconomic policy is appropriate to manage the business cycle and only a central redistributive policy can offset income heterogeneity across localities. Several studies apply this thinking to the European Union given that the principle of subsidiarity (namely, political decisions should be made at the lowest level possible in order to take the preferences of local electorates into account as much as possible) is one of the key principle of the European Union. Stated differently, while it has a different origin, this principle conforms in many respects to the basic views of fiscal federalism (Inman and Rubinfeld, 1992; Gelauff, Grilo, Lejour (eds), 2008). Therefore, many studies consider the EU an optimal solution for exploiting economies of scales and internalizing negative externalities across the national boundaries ${ }^{8}$. For instance Alesina, Angeloni and Etro (2005) considers in a theoretical model the trade-off between the benefits of centralization - coming from economies of scales and externalities - and the costs of harmonizing policies due to the potential increasing heterogeneity of citizens' preferences in a union growing in size as long as new members decide to take part in it. This set-up is applied in Alesina, Angeloni and Schuknecht (2005) to the actual working of the European Union. Obviously, predictions are that policies where economies of scale and/or externalities are predominant should be allocated at the European level, and Member States should be involved instead mainly in those policy areas where heterogeneity of preferences are high relative to economies of scale and externalities. As the authors claim, natural candidates for a deeper EU intervention are policy areas such as international trade, common market, immigration, money and finance, environment and international relations (namely foreign policy, defence and foreign aid). Along the same lines, the authors also suggest that in other policy areas - such as education, research and culture, business relations (sectoral) and citizens and social protection economies of scale and externalities are less obvious and the strength of heterogeneity of preferences overcomes the benefits of economies of scale and internalization of externalities.

\footnotetext{
${ }^{8}$ See Inman and Rubinfeld (1992) and Tabellini (2003). Alesina and Spolaore write: "To some extent the Europe is a union of states that serves the purpose of taking advantages of economies of scales, and creating a level of government with limited prerogatives where benefits of scale are large and heterogeneity of preferences low. The principle of subsidiarity that should be the basis of European integration is consistent with this interpretation" (Alesina and Spolaore, 2003, p. 205).
} 
Bearing in mind this theoretical framework, the authors study the actual policy involvement in the policy areas previously mentioned. It emerges that the actual allocation of EU policy is partly inconsistent with the normative criteria. ${ }^{9}$ On the other hand, using the Eurobarometer survey (Spring 2001 issue), the authors show that citizens' preferences match the normative criteria put forward by economic theory. ${ }^{10}$ In other words, it seems that citizens desire European integration when "it is functional", that is when European integration may be advantageous to exploit economies of scale and it may be desiderable as well in order to internalize externalities. These findings are not dissimilar from other studies (Ahrens et al., 2008; Cerniglia and Pagani, 2009).

In this paper, we choose to go along with this research question. More precisely, the focus of the paper is to understand if information (or political knowledge) is a further variable that can explain Europeans' preferences for (de)centralization in the European Union. To capture empirically the variable to be explained, namely citizens' preference for (de)centralization, the policy areas we consider are: foreign policy, defence, immigration policy, monetary policy, agriculture and fishery policy and regional policy. Quite understandably, as said, these policies fit very well the suggestions coming out when thinking about EU as a federation. Economies of scale in foreign policy and defence are pretty obvious and a common monetary policy is naturally a macroeconomic stabilization policy. As regards immigration, a rationale for centralization comes from the need to internalize the negative externalities arising from free-riding behaviour by member countries. ${ }^{11}$ As for agricultural and fishery policy as well as for regional policy, they have been historically fully in the hand of EU institutions. Such choice has been politically and economically motivated on normative redistributive grounds ${ }^{12}$ (Baldwin and Wyplosz, 2012), although some authors (Bordignon, Buettner and van der Plog 2012; Tabellini 2003) claim that political economy considerations may suggest that these programs need to be scale back to Member States.

\footnotetext{
${ }^{9}$ As the authors claim: "The Eu is too involved in certain areas where economies of scale seem low and heterogeneity of preferences high and not involved enough in others, which, in principle, should have the opposite characteristics" (pag. 312).

${ }^{10}$ For instance they show that there exist a huge favour by citizens for EU involvement in policies related to international relations as well as money and fiscal matters and environment The authors conclude: "In summary, the evidence form the Eurobarometer shows that the preferences of European citizens regarding the allocation of functions between Europe and member countries is remarkably similar to our judgement based on the prediction of theoretical models" (p. 287).

11 Giordani and Ruta (2010) propose also an argument in favour of centralization at the European level of immigration policy as they show, in a theoretical framework, that unilateral behaviour by Member States may lead to coordination failures.

${ }^{12}$ As we all know, basically these programs are transfers from the EU budget to poor regions.
} 
Summing up, in our opinion, these policy areas capture policy issues related to the presence of economies of scale, externalities as well as redistributive and stabilization concerns.

\section{Data and descriptive results}

The empirical analysis is based on Eurobarometer micro-data, an enormous source of information for investigating, monitoring and understanding the attitudes of European citizens towards various issues and policies adopted by the EU. The universe of the survey is citizens aged 15 and over residing in the European Union. To the aim of our work, we use the 2007 Eurobarometer 67.2 edition "European Union Enlargement, Personal Data Privacy, the National Economy, and Scientific Research, April-May 2007", which contains individual information on 30,224 European citizens. We exclude candidate countries' citizens, selecting in this way 26,717 observations. Each survey consists in approximately 1000 face-to-face interviews per UE Member State (except Germany, 1500; Luxembourg, 500; United Kingdom, 1300). ${ }^{13}$

The 67.2 edition of the Eurobarometer has the valuable feature of containing: i) a set of questions about the willingness to pool authority and create a common policy in the areas of defence, foreign policy and immigration; ii) a set of questions that enable assessment of the degree of correct political knowledge possessed by European citizens on some key institutional features of the EU. By combining this information, we are allowed to investigate the relationship between political knowledge and attitudes towards the European Union. Moreover, the 67.2 edition is the only one containing, in addition to the latter questions, suitable instrumental variables for political knowledge that we need in order to deal with the potential endogeneity of information. ${ }^{14}$

\section{TABLE 1}

Beside these questions, the survey collects data on a standard set of demographic and other socio-economic background variables and on citizens' ideology, such as their left/right political position. This is also an important characteristic of the survey, given that some studies have shown that ideology plays a role in shaping individuals' attitudes towards the

\footnotetext{
${ }^{13}$ The empirical analysis is made weighting observations with the "Weight Europe 27" weight (included in the dataset), that includes all 25 member countries after the 2004 enlargement, plus the Accession Countries as of January 2007 (Romania and Bulgaria).

${ }^{14}$ More details on these variables will be provided in Section 4.
} 
European project (Eichenenberg and Dalton, 1993; Hix 2008). The survey also includes a specific set of questions on political trust.

Looking at our sample (see Table 1), on average, respondents are 45 years old, and 52\% are female. Almost one quarter of the sample (23\%) completed education before the age of 15 , $40 \%$ between 16 and 19 and 24\% after the age of 20. As regards labour-market position, retired persons represent $25 \%$ of the sample, a percentage similar to that of manual workers (23\%). The modal value of the political position is centre (34\%), followed by left (27\%) and right (20\%). One fifth of respondents either refuse to answer this question or state that they do not know. The percentages of citizens who trust the national government and parliament are, respectively, $41 \%$ and $43 \%$.

\subsection{Measuring citizens' attitudes for European integration}

To analyze citizens' attitudes we use Eurobarometer's questions that elicit information on citizens' opinions regarding the enhancement of EU involvement in different policy domains. These questions are the basis for building the dependent variables of the econometric analysis. The precise wording of the questions is as follows:

"What is your opinion on each of the following statements? Please tell me for each statement, whether you are for it of against it:

1. A common foreign policy among the member states of the EU, towards other countries

2. A common defence and security policy among EU member states

\section{A European Monetary Union with one single currency, the euro}

In order to gain information on European citizens' opinions on immigration policy as well, we used another question, whose exact wording is:

"Do you tend to agree or tend to disagree with the following statement? The EU should have a common immigration policy towards people from outside the EU"

Finally, in order to elicit information on attitudes regarding agriculture and fishery policy and regional policy, we used Eurobarometer's questions asking whether the respondent thinks that decisions should be made by the own national government or jointly within the European Union.

In our view, the above questions are concrete proposals for a stronger European integration and can yield a good picture of the degree of Europeans' support for (or opposition against) the European Union. 


\subsection{Measuring political knowledge}

As said, the 67.2 Eurobarometer survey contains a set of questions about citizens' objective knowledge about how the EU works. We refer to this knowledge as political knowledge. This is a very important feature of the survey because no solid conclusion could be drawn on the relationship between knowledge and attitudes using subjective (self-declared) knowledge, since this latter can not be verified. The question in the survey used to infer the citizens' level of political knowledge is:

"For each of the following statements about the European Union could you please tell me whether you think it is true or false?

\section{The EU currently consists of fifteen member states}

2. The members of the European Parliament are directly elected by the citizens of the EU

3. Every six months, a different member State becomes the President of the Council of the European Union".

Obviously, these questions investigate citizens' information about only three aspects of the functioning of EU institutions. However, we believe that they are a good proxy for citizens' political knowledge because they regard crucial and basic elements of European institutions.

Among the three questions, the highest percentage of correct answers regards the number of member states, which is correctly known by more than $60 \%$ of respondents, while less than half of the sample (45\%) knows that the members of the European Parliament are directly elected by the citizens of the EU, and just over half (52\%) knows that the President of the Council of the European Union changes every six months. ${ }^{15}$

\subsection{Political knowledge and support for integration}

In this section, we present a first sketch of citizens' opinions for greater European integration and about the relationship between these latter and political knowledge. Overall, a very large majority of respondents (more than 70\%) are in favour of a common policy in the case of foreign policy, defence and immigration (see Table 2). Defence shows the highest percentage of support (77\%), probably because in this policy area citizens much more easily understand the benefits arising from economies of scale. As said, these data come in accordance with previous studies (Alesina, Angeloni and Schuknecht, 2005; Ahrens et al., 2008 and Cerniglia

\footnotetext{
${ }^{15}$ One may think that the high percentage of correct answers regarding the number of Member States is due to the answers provided by New Member States' citizens that had just entered EU in 2007 (in 2004 except Romania and Bulgaria that entered in 2007). However, the shares of citizens answering correctly this question for new members' and old members' citizens are very similar, equal respectively to $61.8 \%$ and $60.8 \%$.
} 
and Pagani, 2009) and they suggest that citizens correctly perceive that greater involvement by the European Union could make the management of these policies more efficient. The support for centralization is $65 \%$ in the case of regional policy and $64 \%$ for monetary policy. The support is lower, compared to the previous areas, but still a majority of citizens prefer a common policy. Things change in the case of agriculture and fishery policy: the majority of citizens (52\%) is in favour of a national competence. This result is not surprising because it comes in accordance with the argument of lower legitimacy and acceptability of redistribution in favour of specific categories of citizens of other Member States (see Tabellini, 2003).

\section{TABLE 2}

On average, male have a more favourable attitude towards greater EU integration. Better educated people have a more positive stance as compared to less educated citizens; the level of consensus is highest among high-skilled workers (professionals and general management) while it is at the lowest level for house persons, retired individuals, unemployed and manual workers. This evidence is consistent with the utilitarian approach above mentioned: highskilled workers are more likely to gain from EU integration, for instance because it allows them to increase their job opportunities and, more in general, to make the most of their human capital. By contrast, low-skilled and unemployed workers are likely to fear the increased competition on the labour market that EU integration may bring. ${ }^{16}$ Oldest citizens (aged 65 and over) are less favourable to a European common policy as compared to citizens of younger ages. Citizens who trust national institutions exhibit a high level of agreement. Regarding ideology, individuals without a declared political position show the lowest consensus for EU with respect to all other citizens. Surprisingly, at least at descriptive level the left-right position of citizens does not seem related to preferences for centralization in any of the policy areas. Finally, it is noteworthy that citizens of new member states are on average better disposed towards a common EU policy compared to EU15 citizens with regard to all the policy areas except monetary policy and agriculture and fishery policy. In a nutshell, the data show that the transfer of power to the EU is not viewed by all citizens as equally desiderable.

\footnotetext{
${ }^{16}$ This result is in line with the utilitarian model of public support for EU integration (see Hix, 2008; Gabel and Palmer, 1995 and Gabel, 1998a).
} 
As a first preliminary evidence of the link between political knowledge and consensus towards EU integration, we show the consensus level for a common policy separately for the six topics and for varying levels of knowledge (see the last rows of Table 2). The Table shows that as political knowledge increases, so does the average consensus for more EU power in all six the considered policy areas. For the whole sample, the average consensus grows from $53 \%$ to $80 \%$ moving from zero to three correct answers in the case of foreign policy, from $63 \%$ to $84 \%$ in the case of defence, from $58 \%$ to $84 \%$ in the case of immigration, from $47 \%$ to $74 \%$ in the case of monetary policy, from $38 \%$ to $58 \%$ in the case of agriculture and fishery policy and from $54 \%$ to $74 \%$ in the case of regional policy.

The right section of Table 2 shows the percentage change in support when moving from zero to three EU institutions known. Very interestingly, knowledge plays a role especially for those respondents on average less well disposed towards Europe. As an example, for the least educated, moving from zero to three EU institutions known is related to an increase in support for EU management of the six policies equal, respectively, to $81 \%$ (foreign policy), 53\% (defence), 67\% (immigration), 64\% (monetary policy), 53\% (agriculture and fishery policy) and $48 \%$ (regional policy).

To sum up, data show that the majority of citizens is in favour of a common policy in the case of foreign affairs, defence, immigration and, to a lesser extent, monetary and regional policy. On the contrary, attitudes are more towards decentralisation in the case of agriculture and fishery policy. Moreover, descriptive evidence suggests both that higher levels of political knowledge are associated with more support for the EU and that there exists a certain degree of variation across citizens as far as this relationship is concerned.

\section{Empirical strategy}

In this section, we describe the empirical approach and discuss some methodological issues. We model the probability to support a greater involvement of EU in policy $i, \operatorname{Pr}\left(S_{i}\right)$ as a function of a vector $X$ of demographic and other socio-economic background variables (age, squared age in order to check for concavity, gender, education, marital status, occupation and home ownership as a proxy for income given that income is not present in the data), on country fixed-effects $C$, on two variables for trust $T$ (whether the respondents trust the national parliament and the national government) and on political ideology variables $I$ (a set of dummies for left/right political positions). Controlling for ideological position is important because it allows distinguishing the effect of citizens' efficiency evaluations about the optimal 
allocation of competencies between the European Union and the member states from the role of their political opinions in shaping their attitudes.

Finally, political knowledge, which is our variable of interest, is included among regressors. As already said, we consider knowledge about some EU institutions. We built one single variable ( $E U$ info) by summing the number of right answers to the questions regarding the functioning of the three EU institutions described in the previous section, so that the variable EU info ranges between zero (no correct answer) and three (all correct answers). In order to facilitate interpretation of results, we dichotomise this variable and thus enter it in the estimation equation as a dummy variable ( $D_{E U}$ info $)$ taking the value of one in the case of high knowledge (two or three correct answers) and zero in the case of low knowledge (zero or one correct answers). ${ }^{17}$ Hence, to model attitudes towards the EU we assume that the probability of being in favour of the $i$-th policy is captured by the following regression equation:

$$
\operatorname{Pr}\left(S_{i}\right)=\alpha+\beta_{1} C+\beta_{2} X+\beta_{3} I+\beta_{4} T+\beta_{5}\left(D_{E U} \text { info }\right)+\varepsilon
$$

Equation (1) is fitted by six standard probit models where the dependent variables are dummy variables taking the value of one when individuals are in favour of, respectively, a common policy on foreign policy, defence and security, immigration, monetary policy, agriculture and fishery and regional policy. Averaging answers on the six policy areas, we observe that $7.3 \%$ of respondents do not have an opinion (the answer is "don't know"). In our analysis, these individuals are merged with the "disagree" category, so that the dependent variables take the value of zero if respondents either disagree or do not have an opinion. ${ }^{18}$

A very important point to take into account is that the estimation of standard regression models assuming that political knowledge is strictly exogenous to opinions on EU leads to biased results if, rather than knowledge having an exogenous causal effect on EU support, knowledge and EU support are jointly determined by underlying factors unobserved in the data. Stated differently, if we want to identify a causal relationship and not a simple correlation between political knowledge and attitudes towards the EU, we must consider that the former variable is likely to be endogenous to attitudes. Endogeneity may arise if there are unobserved factors (like a generic preference for EU) that affect both positive attitudes

\footnotetext{
${ }^{17}$ We replicated estimates including dummy variables for each number of correct answers instead of the dichotomised variable but results were qualitatively unchanged.

${ }^{18}$ We also estimated multinomial logit models with a three-values (agree, do not agree, don't know) dependent variable. However, the results are unchanged. Multinomial logit estimation results are available from the authors upon request.
} 
towards European policies and the extent to which people get informed about the working of EU institutions and, hence, citizens' knowledge simply identifies those respondents who are in favour of European integration.

We deal with endogeneity in two ways. First, we exploit a set of questions present in the 67.2 Eurobarometer survey that allow us to get information regarding the level of citizens' attachment to the EU. These questions are: i) Whether the EU conjures up a positive image; ii) Whether the respondent feels very attached to the EU; and iii) Whether s/he trusts the EU. We built a single variable by considering simultaneously the three questions. This variable, which ranges between zero (minimum degree of Europeanism) and three (maximum degree of Europeanism), should proxy the unobservable generic positive attitude for EU (let us call it 'genuine Europeanism'). If the source of endogeneity is genuine Europeanism, which determines simultaneously preferences and knowledge, this variable should catch the variation in attitudes produced by genuine Europeanism and thus contribute to isolate the causal effect of knowledge on citizens' attitudes.

Second, we use an IV approach and we reach identification using a maximum-likelihood seemingly unrelated two-equation probit model with exclusion restrictions. In order to do so, we have to find valid instruments for political knowledge, that is variables correlated to knowledge but uncorrelated to the error term of the policy opinions equations. The Eurobarometer dataset provides two instrumental variables suitable for this aim. First, we use as instrument citizens' actual knowledge of the main economic indicators of their country. More specifically, the 67.2 Eurobarometer survey contains a set of questions about the growth rate, the inflation rate and the unemployment rate in the respondent's country. The exact wording of each question is:

1. What was the official growth rate of the economy (measured in terms of Gross Domestic Product) in (OUR COUNTRY) in 2006? I can tell you that this figure is between $-1 \%$ and $15 \%$.

2. What was the official inflation rate, the rate of which consumer prices increased or decreased, in (OUR COUNTRY) in 2006? I can tell you that the exact figure is between -1\% and $20 \%$.

3. What was the official unemployment rate, the percentage of active people who do not have a job, in (OUR COUNTRY) in 2006? I can tell you that the exact figure is between $-1 \%$ and $20 \%$. 
We have compared the answers provided by respondents to the actual figures for these economic variables and computed the errors. We built a variable by summing the number of answers characterized by low errors, where an error is considered low when it ranges between zero and two percentage points, and dichotomised this variable so that it takes the value of one when two or three answers to the previous questions are provided with a low error. This variable should catch the propensity to be informed, and thus it should be correlated with political knowledge but not with opinions about the desirability of a common policy in the six areas we consider.

The second instrument is a dummy variable built using the Eurobarometer question where respondents are asked to say whether they agree that it is necessary to know economic figures like the growth rate, inflation rate and unemployment rate. The dummy variable takes the value of one when the respondent totally agree or tend to agree, and zero otherwise (tend to disagree or totally disagree). Also this variable should control for the inclination to get informed, and, as such, it should be correlated with the level of political knowledge about the EU but not with citizens' policy opinions. ${ }^{19}$

Our estimation strategy consists of estimating six two-equation latent dependent-variable models. The estimated models are bivariate probit by which we estimate simultaneously an equation for citizens' attitudes with one endogenous dummy (political knowledge) and one reduced form equation for the endogenous political knowledge dummy. The exclusion restrictions are based on the IV described above. ${ }^{20}$

\section{Results}

In this section, first we will verify whether the positive relationship between political knowledge and attitudes towards EU integration remains after controlling for citizens' observable characteristics and assuming the exogeneity of political knowledge. Second, we will cope with the potential endogeneity of knowledge. Finally, we will also comment on the other estimation results, present results of a falsification test and show some evidence for the post- financial crisis period.

\footnotetext{
${ }^{19}$ Obviously, we can not be completely sure about the exogeneity of these instrumental variables with respect to attitudes, even if the instruments we use are based on actual knowledge (or on the importance the individuals attach to the knowledge) of the economic situation of citizens' own country and it is not referred to the economic situation in Europe. Moreover, note that we control for the main potential source of endogeneity (i.e. "feelings" about the EU) also through the Europeanism variable. On the whole, given the data we use, we believe that this is the best that can be done.

${ }^{20}$ As a robustness check, we estimate also a two-stage linear probability model. Results are in the Appendix.
} 


\subsection{The role of political knowledge}

The upper panel of Table 3 presents probit results when political knowledge is taken as exogenous to attitudes. The Table displays only the coefficients of $E U$ info while complete estimates are shown in the Appendix (see Table A1). In order to facilitate interpretation of the results we report marginal effects.

\section{TABLE 3}

Considering our variable of interest, estimation results widely confirm the positive relationship between political knowledge and citizens' agreement on the assignment of more power to the EU that emerged from descriptive analysis (see Table 2). More specifically, moving from low to high EU knowledge is related to an increase of around $11 \%$ in the probability of being in favour of more EU powers in the field of foreign policy, immigration and monetary policy. The increase amounts to $8.1 \%$ and to $7.6 \%$ in the case of, respectively, defence and regional policy. The lowest coefficient is instead found for agriculture and fishery $(+6.9 \%)$.

The lower panel of Table 3 shows estimates when "genuine Europeanism" is controlled for (see section 3). ${ }^{21}$ This variable should control for the unobservable preference for EU, which is likely to determine simultaneously approval of EU integration and the extent to which citizens inform themselves about the workings of the EU institutions.

First, results in the Table clearly confirm the positive relationship between political knowledge and preferences for centralization, also after controlling for one of the main potential source of endogeneity. Second, our hypothesis that when citizens are keener on the European project, they are more likely both to inform themselves and to be in favour of EU integration is confirmed, as evidenced by the decrease in the coefficients for political knowledge with respect to the specification not controlling for genuine Europeanism shown in the upper panel of Table 3. The highest reduction in the marginal effect of knowledge is found for agriculture and fishery and monetary policy (respectively $-22 \%$ and $-21 \%$ ), and the lowest for immigration, for which we find a reduction in the marginal effect of just $11 \%$.

Overall, these results confirm that estimation of attitudes neglecting that knowledge is jointly determined with Europeanism leads to upward biased results. This means that, at least to

\footnotetext{
${ }^{21}$ Also in this case we show only coefficients of $E U$ info while full estimates are in Table A2 in the Appendix.
} 
some extent, a generic positive attitude towards the EU simultaneously determines knowledge and attitudes towards European integration.

Finally, in order to better tackle the issue of endogenous knowledge, Table 4 shows the results obtained using IV techniques with exclusion restrictions. As a robustness check, we replicate estimation using the two different instruments described before. Moreover, in the Appendix we report results obtained estimating a two-stage linear probability model (see Table A5).

To facilitate the interpretation of empirical results, in this case too the table contains marginal effects computed after bivariate probit estimation. ${ }^{22}$

\section{TABLE 4}

Also the IV approach results confirm an important role for political knowledge and they show that a greater amount of political knowledge has a marked positive effect on positive attitudes towards EU integration. The computed marginal effects do not change greatly when estimated with different instruments: they are $8.6 \%, 6.1 \%, 9.1 \%, 6.2 \%, 4.1 \%$ and $5.3 \%$ respectively for foreign policy, defence, immigration, monetary policy, agriculture and fishery and regional policy when using IV1 and $8.2 \%, 5.4 \%, 8.4 \%, 6.3 \%, 4.2 \%$ and 5.2\% when using IV2. It is also to be noticed that there is a slight decrease in the marginal effects of knowledge with respect to previous estimates; this finding confirms that estimating the effect of knowledge on opinions neglecting endogeneity leads to upward biased results. The reduction in the coefficient of political knowledge from the first to the last model is the strongest in the case of monetary policy (-42\%) and agriculture and fishery $(-40 \%)$, while it is the lowest for immigration policy, with just a $16 \%$ reduction of the coefficient.

\subsection{Other factors affecting citizens' preferences}

Previous empirical studies have shown that citizens of different countries on average have dissimilar preferences regarding EU integration. ${ }^{23}$ For instance, Voessing (2005) shows unambiguously that nationality is the most relevant factor influencing individuals' attitudes towards the EU. Our findings confirm the importance of the country effect. The Nordic country group has in general the lowest support for EU integration, followed by UK; for these

\footnotetext{
${ }^{22}$ More specifically, marginal effects are computed as the difference between the marginal probability of being in favour of centralisation given a high level of political knowledge less the marginal probability of being in favour of centralisation given a low level of political knowledge. We show only the coefficients of political knowledge, while we report full estimates in Tables A3 and A4 in the Appendix.

${ }^{23}$ See Cerniglia and Pagani, (2009).
} 
countries, the highest disagreement is found for monetary policy (with the exception of Finland) and foreign policy. Citizens from new member states and from the Mediterranean group of countries (with the notable exception of Greece for monetary policy) are generally more in favour of greater EU involvement, as well as citizens from Germany and Belgium.

Females are on average slightly less in favour of common policies than men, and in the case of foreign policy, immigration and agriculture and fishery, consensus is increasing and concave in age. As regard the effect of education, results confirm the descriptive evidence by indicating high education as a factor enhancing support for Europe: respondents with the lowest education level are less likely to be in favour of more EU involvement in each policy compared to citizens with the highest education level, with a stronger effect in the case of monetary policy (-20\%) and of foreign policy (-12.8\%). The difference in support between citizens with intermediate-level education and highly-educated citizens ranges between $2.5 \%$ in the case of immigration and $7.7 \%$ in the case of monetary policy.

As regards labour-market position, econometric analysis partially confirms the descriptive results showing that high-skilled workers are more in favour of EU integration: with respect to this latter group, individuals out of the labour force are less likely to demand more common policy in all areas but immigration; also manual workers and unemployed seem less supportive of integration. Home ownership, which is entered as a proxy for income, has no effect on Europeans' preferences.

Leftist citizens have a less positive attitude than both rightist citizens and centrist citizens towards greater EU power in the area of immigration. In contrast, leftist citizens seem more pro-EU as regard monetary policy and agriculture and fishery policy. The lowest consensus level for all policies is instead found for citizens without a declared political position. Trust in one's country's political institutions is related to a more favourable attitude towards common policies for all the six areas analysed.

When controlling for genuine Europeanism some coefficients change (see Table A2). For example, the negative marginal effects previously found for Nordic countries and for UK decrease in size, suggesting that part of the lower consensus for EU in these countries is related to a lower level of Europeanism. Also the coefficients of the education dummy variables decrease and, in the case of intermediate education, they become insignificant for foreign policy, immigration and regional policy. Finally, as expected the variable for genuine Europeanism has a very large and significant coefficient, especially in the case of foreign 
policy and monetary policy, and less so in that of immigration and of regional policy, suggesting that more EU-enthusiastic citizens are more in favour of EU integration. ${ }^{24}$

\subsection{A falsification test for the functional hypothesis}

So far, we have tested citizens' attitudes regarding the vertical allocation of competences only considering some part of this allocation. More specifically, we have focused on six policy areas that strongly exhibit international spill-over effects, economies of scale, stabilization's aim and redistributive effects, and therefore are more efficiently provided at the supranational level. As said, the desire for centralization is quite strong among European citizens in almost all these areas, and political knowledge plays a role in determining these preferences.

We intend to be more convincing about our findings focussing also on policy areas where centralization is not justified anymore because economies of scale and redistributive and stabilization purposes are not predominant and there may be instead the potential existence of heterogeneity of preferences due, for instance, to cultural reasons. In other words, we have to consider public goods whose demand is based mainly on heterogeneous preferences across countries and citizens. This is certainly the case, for instance, of policies regarding the education system. Ahrens et al. (2008) and Mazzaferro and Zanardi (2008) document that in this policy field a clear majority in favour of centralization does not prevail since it is characterized by high heterogeneity among countries and across citizens. Therefore, if considering this policy area we find that: a) the majority of people is not in favour of centralization and b) more knowledgeable people display more favourable attitudes towards national competence, in a sense we should be able to provide a falsiable result on preferences for centralization.

Considering a question in the Eurobarometer asking citizens whether for education policies they think that decisions should be made by their own national government or made jointly within the European Union, we find that the majority of citizens is in favour of a national competence (65.6\%). Still, this result confirms that citizens seem to follow the normative prescription of the fiscal federalism literature.

In order to analyse the role of information on attitudes towards education policy, we reestimate the previous models considering preferences for the allocation of competences

\footnotetext{
${ }^{24}$ These results are in line with those studies arguing that support for integration is also a function of cognitive mobilization and political values (see Gabel, 1998a).
} 
regarding the policy area concerning education system. The following Table 5 show estimation results. $^{25}$

\section{TABLE 5}

Our findings are very encouraging given that, in this case, we do not find the positive effect of political knowledge on attitudes towards centralization that we found before: in our preferred models controlling for endogeneity by means of instrumental variables, the information coefficient turn out to be either non significant or negative and significant, suggesting that more informed citizens are less likely to be in favour of centralization as far as education is concerned, and pointing out that when heterogeneity of preferences is high citizens correctly informed are against centralization of this policy to EU.

\subsection{Political knowledge, attitudes and Europeanism after the financial crisis}

In this section, we try to extend the analysis to more recent data in order to test whether the role of political knowledge has changed after the financial crisis and the extraordinary events happened in Europe since then. Certainly, the current economic and financial situation is such unprecedented in the EU history that we can not ignore whether the perceptions of EU citizens on the role of EU has changed.

However, as before said, the Eurobarometer survey does not provide data after 2007 allowing a proper estimation of the causal effect of information on attitudes. More specifically, different waves after 2007 contain information on preferences for centralization, on political knowledge by citizens and on their Europeanism, but they do not include variables suitable as instruments. Despite of this, we can replicate our analysis on 2012 data and try to control, at least partially, for the endogeneity of information through the inclusion of Europeanism in the equation to be estimated.

Before presenting results, however, other three caveat should be made. First, in the 77.3 edition of the Eurobarometer, opinions regarding preferences for centralization are solicited with identical questions as in the 67.2 edition only with regard to foreign policy, defence and monetary policy. For immigration and for regional policy, instead, the questions we could use to infer attitudes are different from those we used for 2007. More specifically, the May 2012

\footnotetext{
${ }^{25}$ In the Table, we show only the coefficients of political knowledge. Full estimation results are available from the authors upon request.
} 
survey asks respondents the following question: “European integration has been focusing on various issues in the last years. In your opinion, which aspects should be emphasized by the European institutions in the coming years, to strengthen the EU in the future?". We consider the respondent preferring centralization when answering "immigration policy" and "regional development policy" to this question. Admittedly, this question is very different from the one used in the previous analysis, but at least it allows to obtain some insights into preferences for the two policies. Finally, in the case of agriculture and fishery policy there is no question allowing obtaining information on the desired allocation of competencies.

The second caveat regards the political knowledge variable: in the 77.3 edition the true/false question regarding the six-months rotation of the President of the Council of the European Union has been substituted by the following true/false question: "Switzerland is a member of the EU" (the other two questions are the same as in the 2007 survey)", therefore political knowledge is not measurable in the same way in the two surveys.

Finally, in the May 2012 edition there are no questions asking the political position of the respondent, and so we could not control for this variable in the empirical analysis.

With all these caveat in mind, we estimate equation (1) on the 77.3 edition of the Eurobarometer (of May 2012) and present results in Table 6, first treating political knowledge as an exogenous variable (i.e. without controlling for Europeanism, column 1) and then controlling for Europeanism (column 2) ${ }^{26}$.

Remarkably, the Table shows that also on 2012 data information seems to play a positive role in favouring attitudes for centralization. Moreover, comparing results in Table 6 with those in Table 3, it can be noticed that the coefficients are larger for the policies where attitudes can be measured by the same questions, namely foreign policy, defence and monetary policy, while for immigration and regional policy the coefficients are lower in 2007. However, given the differences between the two analysis (both in terms of how the variables have been created and in terms of model specification) a direct comparison of the coefficients' values does not seem correct. Overall, the analysis on more recent post-crisis data does not show a change in the role that political knowledge plays on the process of attitudes' formation: the results of the previous paragraphs are then confirmed.

\footnotetext{
${ }^{26}$ We show only coefficients of political knowledge. Other results are similar to those we found for 2007. Full estimates are available from the authors upon request.
} 


\section{Conclusion}

The findings of this paper show unambiguously that most competent people are more likely to favour European integration. Specifically, we found that Europeans' attitudes regarding the vertical allocation of competences in the European Union are significantly shaped by the political knowledge that they possess about the correct functioning of some European institutions and that they are more in favour of common EU policies when economies of scale are high, heterogeneity of preferences is low and a redistributive or stabilization function is to be pursued. These results hold also when considering the potential endogeneity of political knowledge with respect to attitudes and when controlling for ideology that, at first glance, may be thought as one of the main determinant of policy opinions regarding EU integration. Our findings point out as well that estimation of attitudes neglecting that knowledge is jointly determined with genuine Europeanism leads to biased results, suggesting that a positive attitude towards the EU simultaneously determines knowledge and policy opinions. We are quite confident about the goodness of our results since they have been obtained: i) for a number of policy areas where normative suggestions for a centralized solution rely on the presence of externalities, economies of scale and on the stabilization and redistributive role of the central government; ii) for a policy area where heterogeneity of preferences among citizens is the driving force that call for a decentralized solution; iii) in the present contest of the economic crisis, where there is still a common idea among European citizens on what should be centralized, but the support is declined.

These results are of great importance for two main reasons. Firstly, in the contemporary economic literature the role of information in shaping policy preferences is receiving increasing attention for explaining policy choices (see Boeri and Tabellini, 2012; Clark and Hellwing, 2012 and the references therein). In this regard, our findings suggest that wellinformed citizens are better able to assess the consequences of alternative policy proposals. Second, we believe that our results have a crucial policy relevance in the present context of increasing Euroscepticism. There is no doubt - as documented in many studies (see Serricchio et al. 2013 and references therein) - that there is a link between the global financial crisis and the increase in Euroscepticism, as measured by the standard measure of citizens' support for European integration. In this paper, we have considered different measures to capture support for integration in specific policy areas, and also in this case we have observed a decline in support. As argued by many scholars ${ }^{27}$, this decline is an impressive picture of the

\footnotetext{
${ }^{27}$ see Laconte (2010), Usherwood and Startin (2013).
} 
redistributive struggles that European citizens are facing nowadays on the perceived benefits and costs deriving from the current state of affairs of the EU, embedded in an unprecedented phase of uncertainty.

Our paper tell us, however, that public support for the EU can be influenced by rendering citizens better informed about the EU. We confirm then both the conventional wisdom of part of the European Commission and predictions of the early theoretical literature on European integration (Gabel, 1998a and 1998b) that raising awareness about the EU can help creating greater commitment to European integration among European citizens. 
APPENDIX

TABLES A1, A2, A3, A4, A5 


\section{References}

Alesina, A., Angeloni, I., and Etro, F., 2005. International Unions. The American Economic Review. 5, 602-615.

Alesina, A., Angeloni, I., Schuknecht, L., 2005. What does the European Union do?. Public Choice. 123, 275-319.

Alesina, A., Fuchs-Schundeln, N., 2007. Good Bye Lenin (or not?) - The Effect of Communism on People's Preferences. American Economic Review. 97, 1507-1528.

Alesina, A., Spolaore, E., 2003. The Size of Nations. MIT Press, Cambridge, MA.

Ahrens, J., Meurers, M., Renner, C., 2008. Who shall decide what? Citizens' attitudes towards political decision making in the EU, in: Gelauff, G., Grilo, I., Lejour, A. (Eds), Subsidiarity and Economic Reform in Europe. Springer, Berlin, pp. 41-58.

Baldwin, R., Wyplosz, C., 2012. The Economics of European Integration, McGraw-Hill

Bijsman, P., Altides, , C., 2007. Bridging the Gap' between EU Politics and Citizens? The European Commission, National Media and EU Affairs in the Public Sphere. European Integration. 29, 323-340.

Blinder, A.S., Krueger, A.B., 2004. What does the public know about economic policy, and how does it know it?. Brookings Papers on Economic Activity. 35, 327-397.

Boeri, T., Tabellini, G., 2012. Does information increase political support for pension reform?. Public Choice. 150, 327-362

Bordignon, M., Buettner, T., van der Ploeg F., 2012. Europe at a Crossroads: Reforming Political Institutions and Public Sectors in Thiess Buettner T. , Wolfgang Ochel, W., (eds) The Contiuous Evolution of Europe. Cesifo Seminar Series. Mitt Press, London

Cerniglia, F., Pagani, L., 2009. The European Union and the Member States: An empirical analysis of Europeans' preferences for competence allocation. CESifo Economic Studies. 55, 197-232.

Clark, N., Hellwing, T., 2012. Information effects and mass support for EU policy control. European Union Politics. Published on line 29 march 2012.

Citrin, J. and Sides,, J. (2004) More Than National, How identity choice matter in the new Europe, in Hermann, R.K. Risse, T. Brewer, M.B., (eds), Transnational identities: becoming European in EU, Lanham, Rowman and Littlefield.

Commission of the European Communities, 2006. White paper on a European Communication Policy, Com (2006)35 final. Brussels, 1.2.2006.

Eichenberg, R., Dalton, R., 1993. Europeans and the European Community: the dynamics of public support for European integration. International Organization. 47, 507-534.

Eichenberg, R., Dalton, R., 2007. Post-Maastricht Blues: The Transformation of Citizen Support for European Integration, 1973-2004. Acta Politica. 42, 128-152

Facchini, G., Mayda, A.M., 2008. From Individual Attitudes towards Migrants to Migration Policy Outcomes: Theory and Evidence. Economic Policy. 56, 651-713.

Gabel, M.J., 1998a. Public support for European Integration: An empirical test of five theories. Journal of Politics. 60, 333-354. 
Gabel, M.J., 1998b. Interest and Integration: Market liberalization, Public Opinion, and European Union. University of Michigan Press, Ann Arbor.

Gabel, M.J., Palmer, H., 1995. Understanding variation in Public support for European Integration. European Journal of Political Research. 27, 3-19.

Gelauff, G., Grilo, I., Lejour, A. (Eds), 2008. Subsidiarity and Economic Reform in Europe. Springer, Berlin.

Giordani, P.E., Ruta, M., 2010. Coordination Failures in Immigration Policy, WTO Staff working paper.

Hix, S., 2008. What's wrong with the European Union and how to fix it. Polity Press, Cambridge.

Hooghe, L. 2003. Europe divided? Elites vs. public opinion on European integration. European Union Politics. 4, 281-304.

Inman, R., Rubinfeld, D., 1992. Fiscal federalism in Europe. Lesson from the United States experience. European Economic Review. 36, 654-660.

Laconte, C., 2010. Understanding Euroscepticism. Palgrave Macmillan.

Mazzaferro, C., Zanardi, A., 2008. Centralization versus Decentralization of Public Policies: Does the Heterogeneity of Individual Preferences Matter? Fiscal Studies. 29, pp. 35-73

Oates, W., 1972. Fiscal Federalism. Harcourt Brace Jovanovich, New York.

Oates, W., 1999. An Essay on Fiscal Federalism, Journal of Economic Literature. 37, 11201149

Page, B., Shapiro, R., 1983. Effect of Public Opinion on Policy. American Political Science Review. 77, 175-190.

Serricchio, F., Tsakatika, M., Quaglia, L., 2013. Euroscepticism and the Global Financial Crisis. Journal of Common Market Studies. 51, 51-64.

Tabellini, G., 2003. Principles of Policymaking in the European Union: An Economic Perspective. CESifo Economic Studies. 49, pp. 75-102.

Usherwood, S., Startin, N., 2013. Euroscepticism as a Persistent Phenomenon. Journal of Common Market Studies. 51, pp 1-16.

Voessing, K. (2005) Nationality and the preferences of the European public toward EU-policy making. European Union Politics. 6. 445-467 
Table 1. Sample characteristics

\begin{tabular}{|c|c|c|}
\hline Variable & Mean & Std. Dev. \\
\hline \multicolumn{3}{|l|}{ Demographics } \\
\hline Female & 0.52 & 0.50 \\
\hline Age & 45.7 & 18.5 \\
\hline Married & 0.60 & 0.49 \\
\hline \multicolumn{3}{|l|}{ Age at completed education } \\
\hline$<=15$ & 0.23 & 0.42 \\
\hline $15-19$ & 0.40 & 0.49 \\
\hline$>=20$ & 0.24 & 0.43 \\
\hline Still studying & 0.10 & 0.31 \\
\hline Other & 0.02 & 0.15 \\
\hline \multicolumn{3}{|l|}{ Occupation } \\
\hline House person & 0.09 & 0.28 \\
\hline Student & 0.10 & 0.31 \\
\hline Unemployed & 0.06 & 0.24 \\
\hline Retired & 0.25 & 0.43 \\
\hline Manual worker & 0.23 & 0.42 \\
\hline Low-skilled white-collar & 0.11 & 0.31 \\
\hline High-skilled whithe-collar & 0.12 & 0.32 \\
\hline Businessman & 0.05 & 0.21 \\
\hline \multicolumn{3}{|l|}{ Ideology } \\
\hline Left & 0.27 & 0.44 \\
\hline Right & 0.20 & 0.40 \\
\hline Centre & 0.34 & 0.47 \\
\hline Refusal/don't know & 0.20 & 0.40 \\
\hline \multicolumn{3}{|l|}{ Trust } \\
\hline National Government & 0.41 & 0.49 \\
\hline National Parliament & 0.43 & 0.49 \\
\hline Nr observations & 26,082 & \\
\hline
\end{tabular}


Table 2. Support for EU integration and political knowledge

\begin{tabular}{|c|c|c|c|c|c|c|c|c|c|c|c|c|}
\hline & \multicolumn{6}{|c|}{ Average consensus ${ }^{\mathrm{a}}$} & \multicolumn{6}{|c|}{$\%$ change in support ${ }^{b}$} \\
\hline & $\begin{array}{c}\text { Foreign } \\
\text { policy }\end{array}$ & Defence & Immigration & $\begin{array}{c}\text { Monetary } \\
\text { policy }\end{array}$ & $\begin{array}{l}\text { Agricolture } \\
\text { and fishery }\end{array}$ & $\begin{array}{c}\text { Regional } \\
\text { policy }\end{array}$ & $\begin{array}{c}\text { Foreign } \\
\text { policy }\end{array}$ & Defence & Immigration & $\begin{array}{c}\text { Monetary } \\
\text { policy }\end{array}$ & $\begin{array}{l}\text { Agricolture } \\
\text { and fishery }\end{array}$ & $\begin{array}{c}\text { Regional } \\
\text { policy }\end{array}$ \\
\hline Whole sample & 0.71 & 0.77 & 0.75 & 0.64 & 0.48 & 0.65 & & & & & & \\
\hline \multicolumn{13}{|l|}{ Demographics } \\
\hline Male & 0.74 & 0.80 & 0.78 & 0.69 & 0.52 & 0.68 & 0.44 & 0.26 & 0.40 & 0.49 & 0.50 & 0.30 \\
\hline Female & 0.68 & 0.75 & 0.73 & 0.59 & 0.46 & 0.63 & 0.52 & 0.34 & 0.46 & 0.55 & 0.49 & 0.38 \\
\hline Age 15-24 & 0.72 & 0.81 & 0.74 & 0.70 & 0.48 & 0.69 & 0.44 & 0.26 & 0.35 & 0.34 & 0.54 & 0.25 \\
\hline Age $25-34$ & 0.71 & 0.79 & 0.76 & 0.69 & 0.52 & 0.69 & 0.41 & 0.25 & 0.33 & 0.38 & 0.31 & 0.33 \\
\hline Age $35-44$ & 0.73 & 0.79 & 0.77 & 0.66 & 0.50 & 0.66 & 0.39 & 0.21 & 0.29 & 0.45 & 0.46 & 0.23 \\
\hline Age $45-54$ & 0.71 & 0.79 & 0.77 & 0.64 & 0.52 & 0.67 & 0.36 & 0.23 & 0.38 & 0.45 & 0.38 & 0.22 \\
\hline Age 55-64 & 0.71 & 0.77 & 0.77 & 0.62 & 0.48 & 0.64 & 0.52 & 0.35 & 0.51 & 0.63 & 0.69 & 0.51 \\
\hline Age $65+$ & 0.66 & 0.72 & 0.72 & 0.55 & 0.43 & 0.60 & 0.80 & 0.58 & 0.73 & 1.14 & 0.72 & 0.57 \\
\hline \multicolumn{13}{|l|}{ Age at completed education } \\
\hline$<=15$ & 0.62 & 0.69 & 0.68 & 0.50 & 0.43 & 0.58 & 0.81 & 0.53 & 0.67 & 0.64 & 0.53 & 0.48 \\
\hline $16-19$ & 0.73 & 0.79 & 0.77 & 0.64 & 0.47 & 0.66 & 0.38 & 0.24 & 0.37 & 0.44 & 0.38 & 0.28 \\
\hline$>=20$ & 0.75 & 0.82 & 0.80 & 0.72 & 0.55 & 0.70 & 0.27 & 0.15 & 0.22 & 0.40 & 0.42 & 0.23 \\
\hline \multicolumn{13}{|l|}{ Labour market position } \\
\hline house person & 0.66 & 0.69 & 0.71 & 0.58 & 0.47 & 0.63 & 0.60 & 0.46 & 0.53 & 0.41 & 0.45 & 0.54 \\
\hline student & 0.73 & 0.82 & 0.74 & 0.74 & 0.50 & 0.70 & 0.44 & 0.20 & 0.34 & 0.27 & 0.75 & 0.24 \\
\hline unemployed & 0.68 & 0.74 & 0.72 & 0.60 & 0.48 & 0.63 & 0.56 & 0.38 & 0.55 & 0.47 & 0.44 & 0.37 \\
\hline retired & 0.68 & 0.74 & 0.73 & 0.56 & 0.44 & 0.61 & 0.69 & 0.48 & 0.65 & 1.02 & 0.70 & 0.52 \\
\hline manual worker & 0.70 & 0.78 & 0.75 & 0.63 & 0.48 & 0.65 & 0.41 & 0.23 & 0.41 & 0.45 & 0.37 & 0.20 \\
\hline low-skilled white-collar & 0.74 & 0.81 & 0.80 & 0.69 & 0.51 & 0.67 & 0.26 & 0.13 & 0.21 & 0.23 & 0.36 & 0.27 \\
\hline high-skilled white-collar & 0.78 & 0.83 & 0.81 & 0.74 & 0.57 & 0.71 & 0.30 & 0.18 & 0.19 & 0.43 & 0.30 & 0.17 \\
\hline businessman & 0.75 & 0.82 & 0.79 & 0.70 & 0.51 & 0.69 & 0.38 & 0.21 & 0.21 & 0.26 & 0.45 & 0.40 \\
\hline \multicolumn{13}{|l|}{ Ideology } \\
\hline Left & 0.72 & 0.77 & 0.76 & 0.66 & 0.53 & 0.67 & 0.37 & 0.27 & 0.36 & 0.52 & 0.49 & 0.31 \\
\hline Right & 0.73 & 0.81 & 0.77 & 0.67 & 0.48 & 0.66 & 0.41 & 0.24 & 0.35 & 0.42 & 0.62 & 0.43 \\
\hline Centre & 0.73 & 0.79 & 0.78 & 0.65 & 0.49 & 0.66 & 0.38 & 0.22 & 0.28 & 0.52 & 0.44 & 0.29 \\
\hline Refusal/don't know & 0.64 & 0.71 & 0.67 & 0.56 & 0.43 & 0.61 & 0.81 & 0.53 & 0.79 & 0.66 & 0.45 & 0.38 \\
\hline \multicolumn{13}{|l|}{ Trust } \\
\hline National Government & 0.76 & 0.82 & 0.80 & 0.73 & 0.53 & 0.69 & 0.36 & 0.24 & 0.35 & 0.44 & 0.50 & 0.29 \\
\hline National Parliament & 0.75 & 0.81 & 0.80 & 0.72 & 0.54 & 0.69 & 0.34 & 0.23 & 0.32 & 0.40 & 0.47 & 0.29 \\
\hline \multicolumn{13}{|l|}{ Country } \\
\hline EU15 & 0.68 & 0.74 & 0.75 & 0.65 & 0.50 & 0.63 & 0.54 & 0.37 & 0.40 & 0.55 & 0.50 & 0.43 \\
\hline New Member States & 0.74 & 0.83 & 0.76 & 0.61 & 0.46 & 0.68 & 0.50 & 0.34 & 0.54 & 0.56 & 0.54 & 0.31 \\
\hline \multicolumn{13}{|l|}{ EU info ( $n r$ correct answers) } \\
\hline 0 & 0.53 & 0.63 & 0.58 & 0.47 & 0.38 & 0.54 & - & - & - & - & - & - \\
\hline 1 & 0.69 & 0.77 & 0.73 & 0.60 & 0.46 & 0.64 & - & - & - & - & - & - \\
\hline 2 & 0.76 & 0.82 & 0.81 & 0.69 & 0.50 & 0.66 & - & - & - & - & - & - \\
\hline 3 & 0.80 & 0.84 & 0.84 & 0.74 & 0.58 & 0.74 & - & - & - & - & - & - \\
\hline
\end{tabular}

$\mathrm{b}$ : \% change in support moving from 0 to $3 \mathrm{EU}$ institutions known 
Table 3. Marginal effect of information

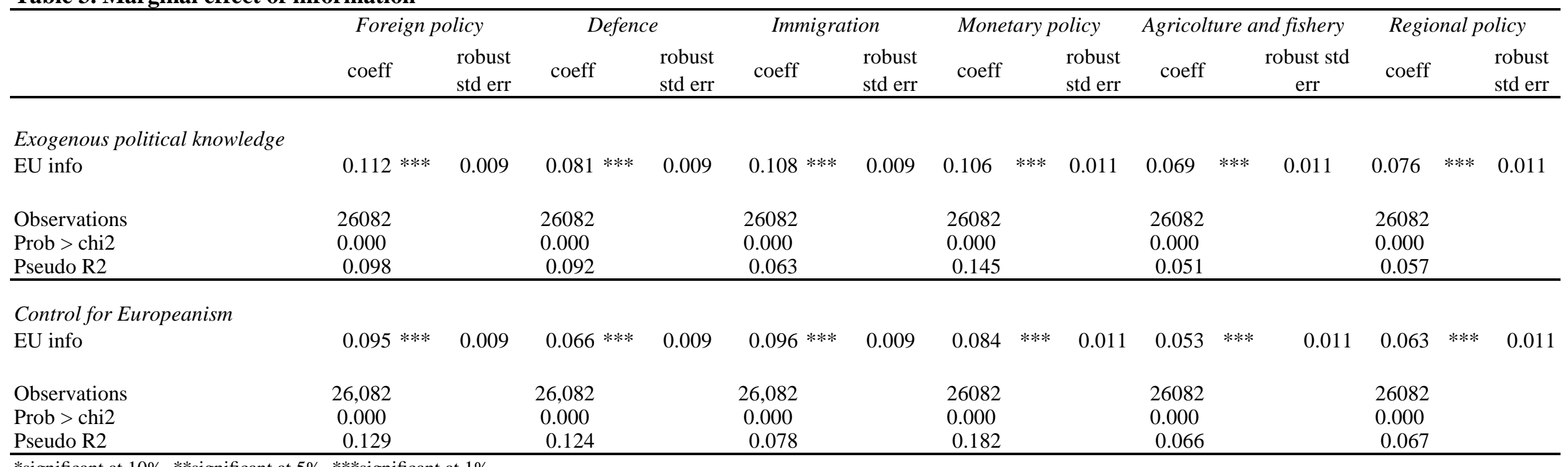

*significant at $10 \%, * *$ significant at $5 \%, * * *$ significant at $1 \%$. 
Table 4. Marginal effect of information - IV estimation

\begin{tabular}{lcc}
\hline & IV $1^{\mathrm{a}}$ & $\mathrm{IV} 2^{\mathrm{b}}$ \\
\hline Foreign policy & $0.086 * * *$ & $0.082 * * *$ \\
Defence & $0.061 * *$ & $0.054 * * *$ \\
Immigration & $0.091 * * *$ & $0.084 * * *$ \\
Monetary policy & $0.062 * * *$ & $0.063 * * *$ \\
Agricolture and fishery & $0.041 * * *$ & $0.042 * * *$ \\
Regional policy & $0.053 * *$ & $0.052 * * *$ \\
\hline \hline
\end{tabular}

****significant at $1 \%, * *$ significant at $5 \%$.

a. IV: 1 if the individual knows 2 or 3 economic indicators with a low error

b. IV: 1 if the individual agrees that it is necessary to know economic figures like the growth rate,

inflation rate and unemployment rate 
Table 5. Marginal effect of information (education system)

\begin{tabular}{lllll}
\hline & $\begin{array}{c}\text { Without } \\
\text { europeanism }\end{array}$ & $\begin{array}{c}\text { Control for } \\
\text { europeanism }\end{array}$ & IV $1^{\mathrm{a}}$ & IV2 $^{\mathrm{b}}$ \\
\hline Preference for EU common policy & $0.0175 *$ & 0.0033 & 0.0032 & $-0.0001 * *$ \\
\hline \hline
\end{tabular}

**significant at 5\%, *significant at 10\%

a. IV: 1 if the individual knows 2 or 3 economic indicators with a low error

b. IV: 1 if the individual agrees that it is necessary to know economic figures like the growth rate,

inflation rate and unemployment rate 
Table 6. Marginal effect of information after the economic and financial crisis

\begin{tabular}{lccccc}
\hline & \multicolumn{2}{c}{ Without europeanism } & \multicolumn{2}{c}{$\begin{array}{c}\text { Control for } \\
\text { europeanism }\end{array}$} \\
\hline Foreign policy & coeff & $\begin{array}{c}\text { robust std } \\
\text { err }\end{array}$ & coeff & $\begin{array}{c}\text { robust std } \\
\text { err }\end{array}$ \\
Defence & $0.1886 * * *$ & 0.011 & $0.181 * * *$ & 0.011 \\
Immigration & $0.1567 * * *$ & 0.010 & $0.150 * * *$ & 0.010 \\
Monetary policy & $0.0416^{* * *}$ & 0.010 & $0.042 * * *$ & 0.010 \\
Regional policy & $0.1533^{* * *}$ & 0.012 & $0.144 * * *$ & 0.012 \\
\hline ***significant at 1\%. & $0.0228^{*} * *$ & 0.007 & $0.022^{* * *}$ & 0.007 \\
\hline
\end{tabular}

***significant at $1 \%$. 
Table A1. Marginal effects on the probability of consensus fo more EU integration - Exogenous political knowledge

\begin{tabular}{|c|c|c|c|c|c|c|}
\hline \multirow[b]{2}{*}{ Variable } & \multicolumn{2}{|c|}{ Foreign policy } & \multicolumn{2}{|c|}{ Defence } & \multicolumn{2}{|c|}{ Immigration } \\
\hline & coeff & $\begin{array}{c}\text { robust std } \\
\text { err }\end{array}$ & coeff & $\begin{array}{c}\text { robust std } \\
\text { err }\end{array}$ & coeff & $\begin{array}{c}\text { robust std } \\
\text { err }\end{array}$ \\
\hline \multicolumn{7}{|l|}{ Country-groups (ref. Italy) } \\
\hline Belgium & $-0.046^{*}$ & 0.025 & $0.062 * * *$ & 0.017 & $0.048 * *$ & 0.019 \\
\hline Denmark & $-0.340 * * *$ & 0.028 & $-0.180 * * *$ & 0.028 & $-0.154 * * *$ & 0.027 \\
\hline Germany & $0.048 * *$ & 0.021 & $0.064 * * *$ & 0.018 & $0.054 * * *$ & 0.019 \\
\hline Greece & 0.005 & 0.023 & 0.030 & 0.018 & $0.072 * * *$ & 0.017 \\
\hline Spain & 0.020 & 0.022 & 0.010 & 0.020 & 0.029 & 0.020 \\
\hline Finland & $-0.281 * * *$ & 0.028 & $-0.246^{* * *}$ & 0.028 & $-0.210 * * *$ & 0.027 \\
\hline France & $-0.099 * * *$ & 0.025 & 0.016 & 0.019 & -0.011 & 0.021 \\
\hline Ireland & $-0.125 * * *$ & 0.025 & $-0.205^{* * *}$ & 0.025 & $-0.076^{* * *}$ & 0.023 \\
\hline Luxemburg & $-0.122 * * *$ & 0.031 & -0.004 & 0.024 & $-0.077 * * *$ & 0.029 \\
\hline Netherlands & $-0.226 * * *$ & 0.027 & $-0.062 * * *$ & 0.024 & -0.023 & 0.023 \\
\hline Austria & $-0.144 * * *$ & 0.026 & $-0.149 * * *$ & 0.025 & $-0.081 * * *$ & 0.024 \\
\hline Portugal & $-0.123 * * *$ & 0.025 & $-0.062 * * *$ & 0.022 & $-0.097 * * *$ & 0.024 \\
\hline Sweden & $-0.381 * * *$ & 0.027 & $-0.275^{* * *}$ & 0.028 & $-0.134 * * *$ & 0.027 \\
\hline UK & $-0.263 * * *$ & 0.026 & $-0.216^{* * *}$ & 0.025 & $-0.074 * * *$ & 0.023 \\
\hline Cyprus & -0.018 & 0.030 & $0.103 * * *$ & 0.018 & $0.072 * * *$ & 0.022 \\
\hline Czech Republic & $-0.106 * * *$ & 0.026 & $0.085^{* * *}$ & 0.016 & $0.077 * * *$ & 0.017 \\
\hline Estonia & $-0.091 * * *$ & 0.025 & $0.057 * * *$ & 0.017 & $-0.074 * * *$ & 0.023 \\
\hline Hungary & 0.014 & 0.022 & 0.024 & 0.019 & $0.036^{*}$ & 0.019 \\
\hline Latvia & -0.008 & 0.023 & $0.092 * * *$ & 0.014 & 0.006 & 0.020 \\
\hline Lithuania & 0.028 & 0.021 & $0.074 * * *$ & 0.015 & $0.032 *$ & 0.019 \\
\hline Malta & $-0.200 * * *$ & 0.033 & $-0.175^{* * *}$ & 0.031 & -0.043 & 0.028 \\
\hline Poland & $0.070 * * *$ & 0.020 & $0.086^{* * *}$ & 0.016 & 0.028 & 0.020 \\
\hline Slovakia & -0.036 & 0.025 & $0.063 * * *$ & 0.017 & 0.014 & 0.021 \\
\hline Slovenia & $0.042 * *$ & 0.021 & $0.085 * * *$ & 0.015 & $0.054 * * *$ & 0.018 \\
\hline Bulgaria & -0.023 & 0.023 & 0.030 & 0.018 & $-0.042 *$ & 0.022 \\
\hline Romania & $-0.067 * * *$ & 0.024 & 0.024 & 0.018 & $-0.092 * * *$ & 0.023 \\
\hline \multicolumn{7}{|l|}{ Demographics } \\
\hline female & $-0.028 * * *$ & 0.009 & $-0.019 * *$ & 0.008 & $-0.031 * * *$ & 0.009 \\
\hline married & $0.025 * *$ & 0.010 & $0.021 * *$ & 0.009 & 0.012 & 0.009 \\
\hline age & $0.004 * *$ & 0.001 & 0.001 & 0.001 & $0.005 * * *$ & 0.001 \\
\hline squared age & $-0.000 * *$ & 0.000 & -0.000 & 0.000 & $-0.000 * * *$ & 0.000 \\
\hline \multicolumn{7}{|c|}{ Age at completed education ( ref. $>=20$ ) } \\
\hline$<=15$ & $-0.128 * * *$ & 0.016 & $-0.084 * * *$ & 0.015 & $-0.078 * * *$ & 0.015 \\
\hline $16-19$ & $-0.029 * *$ & 0.012 & $-0.037 * * *$ & 0.011 & $-0.025 * *$ & 0.011 \\
\hline \multicolumn{7}{|c|}{ Labour market position(ref. High-skilled white-collar) } \\
\hline unemployed & -0.027 & 0.024 & $-0.041 *$ & 0.023 & -0.013 & 0.023 \\
\hline manual worker & $-0.033 *$ & 0.018 & -0.003 & 0.016 & -0.002 & 0.016 \\
\hline low-skilled white-collar & -0.017 & 0.020 & -0.020 & 0.019 & -0.001 & 0.018 \\
\hline businessman & -0.029 & 0.026 & -0.004 & 0.024 & -0.026 & 0.026 \\
\hline out of the labour force & $-0.035 * *$ & 0.017 & $-0.034 * *$ & 0.016 & -0.012 & 0.016 \\
\hline House owned & 0.004 & 0.010 & -0.005 & 0.010 & 0.015 & 0.010 \\
\hline \multicolumn{7}{|l|}{ Trust } \\
\hline national government & $0.047 * * *$ & 0.014 & $0.044 * * *$ & 0.012 & $0.029 * *$ & 0.013 \\
\hline national parliament & $0.067 * * *$ & 0.014 & $0.043 * * *$ & 0.013 & $0.055 * * *$ & 0.013 \\
\hline \multicolumn{7}{|l|}{ Ideology (ref. Left) } \\
\hline right & -0.012 & 0.013 & 0.003 & 0.012 & $0.021 *$ & 0.012 \\
\hline centre & 0.010 & 0.012 & 0.011 & 0.011 & $0.038 * * *$ & 0.011 \\
\hline refusal/don't know & $-0.078 * * *$ & 0.015 & $-0.052 * * *$ & 0.014 & $-0.030 * *$ & 0.013 \\
\hline EU info & $0.112 * * *$ & 0.009 & $0.081 * * *$ & 0.009 & $0.108 * * *$ & 0.009 \\
\hline Observations & 26082 & & 26082 & & 26082 & \\
\hline Prob > chi2 & 0.000 & & 0.000 & & 0.000 & \\
\hline Pseudo R2 & 0.098 & & 0.092 & & 0.063 & \\
\hline
\end{tabular}

*** $\mathrm{p}<0.01, * * \mathrm{p}<0.05, * \mathrm{p}<0.1$

Robust standard errors in parentheses 
Table A1 (cont'd). Marginal effects on the probability of consensus fo more EU integration - Exogenous political knowledge

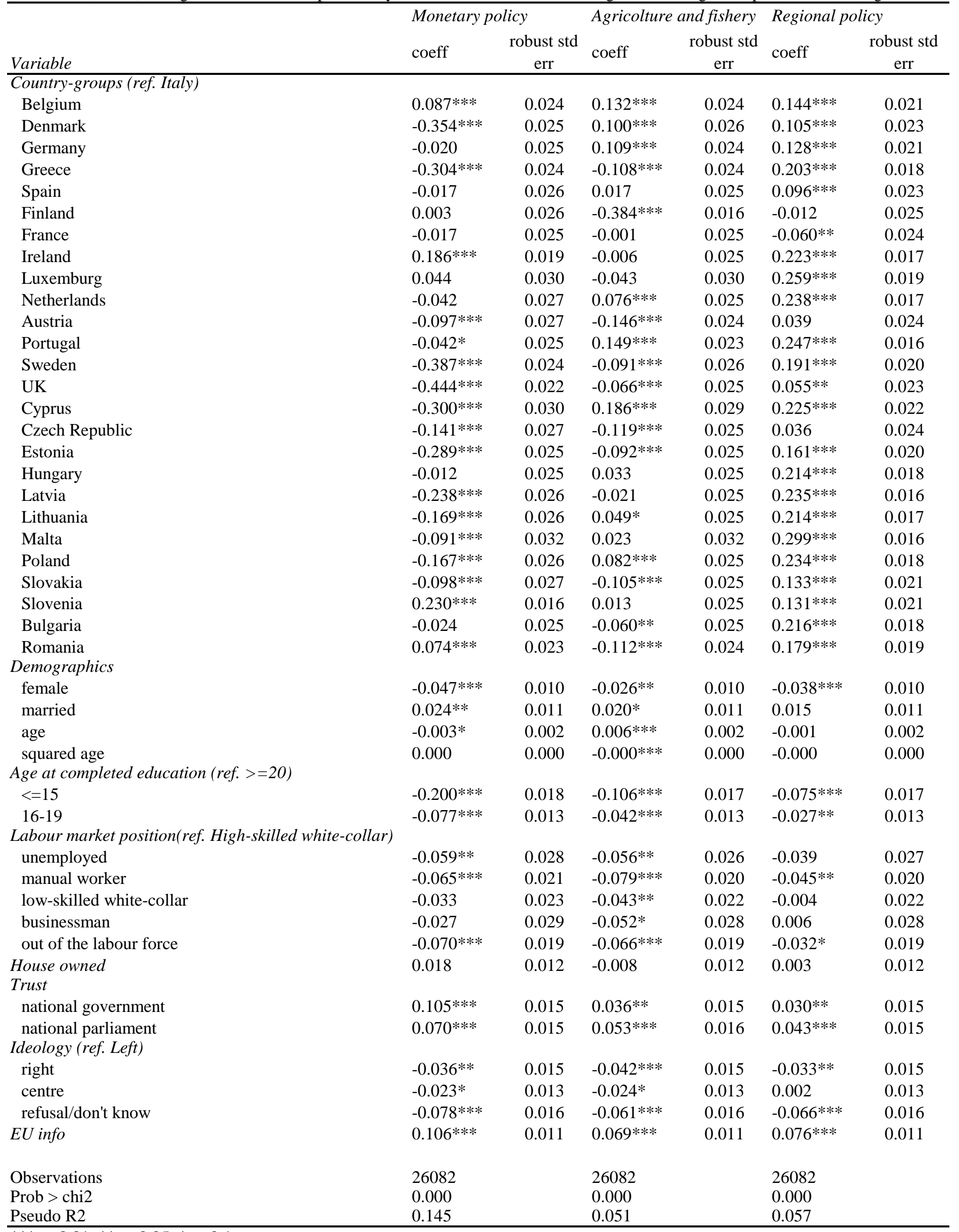

$* * * \mathrm{p}<0.01, * * \mathrm{p}<0.05, * \mathrm{p}<0.1$

Robust standard errors in parentheses 
Table A2. Marginal effect on the probability of consensus fo more EU integration - Control for europeanism

\begin{tabular}{|c|c|c|c|c|c|c|}
\hline \multirow[b]{2}{*}{ Variable } & \multicolumn{2}{|c|}{ Foreign policy } & \multicolumn{2}{|l|}{ Defence } & \multicolumn{2}{|c|}{ Immigration } \\
\hline & coeff & $\begin{array}{l}\text { robust std } \\
\text { err }\end{array}$ & coeff & $\begin{array}{l}\text { robust std } \\
\text { err }\end{array}$ & coeff & $\begin{array}{l}\text { robust std } \\
\text { err }\end{array}$ \\
\hline \multicolumn{7}{|l|}{ Country-groups (ref. Italy) } \\
\hline Belgium & -0.035 & 0.024 & $0.070 * * *$ & 0.016 & $0.055 * * *$ & 0.019 \\
\hline Denmark & $-0.273 * * *$ & 0.029 & $-0.109 * * *$ & 0.026 & $-0.105 * * *$ & 0.026 \\
\hline Germany & $0.073 * * *$ & 0.020 & $0.086^{* * *}$ & 0.016 & $0.069 * * *$ & 0.018 \\
\hline Greece & 0.026 & 0.022 & $0.049 * * *$ & 0.017 & $0.084 * * *$ & 0.016 \\
\hline Spain & 0.025 & 0.022 & 0.016 & 0.019 & $0.034 *$ & 0.020 \\
\hline Finland & $-0.196 * * *$ & 0.028 & $-0.157 * * *$ & 0.027 & $-0.150 * * *$ & 0.027 \\
\hline France & $-0.068 * * *$ & 0.024 & $0.043 * *$ & 0.018 & 0.009 & 0.020 \\
\hline Ireland & $-0.116^{* * *}$ & 0.025 & $-0.193 * * *$ & 0.026 & $-0.069 * * *$ & 0.023 \\
\hline Luxemburg & $-0.094 * * *$ & 0.031 & 0.021 & 0.023 & $-0.057 * *$ & 0.029 \\
\hline Netherlands & $-0.169 * * *$ & 0.027 & -0.012 & 0.021 & 0.009 & 0.021 \\
\hline Austria & $-0.086 * * *$ & 0.026 & $-0.091 * * *$ & 0.024 & $-0.044^{*}$ & 0.023 \\
\hline Portugal & $-0.129 * * *$ & 0.026 & $-0.062 * * *$ & 0.022 & $-0.098 * * *$ & 0.024 \\
\hline Sweden & $-0.323 * * *$ & 0.028 & $-0.206 * * *$ & 0.028 & $-0.091 * * *$ & 0.026 \\
\hline UK & $-0.206^{* * *}$ & 0.026 & $-0.156 * * *$ & 0.024 & $-0.038^{*}$ & 0.022 \\
\hline Cyprus & 0.015 & 0.028 & $0.120 * * *$ & 0.015 & $0.089 * * *$ & 0.020 \\
\hline Czech Republic & $-0.099 * * *$ & 0.026 & $0.089 * * *$ & 0.015 & $0.082 * * *$ & 0.017 \\
\hline Estonia & $-0.066 * * *$ & 0.025 & $0.072 * * *$ & 0.015 & $-0.056 * *$ & 0.023 \\
\hline Hungary & -0.000 & 0.022 & 0.014 & 0.019 & 0.029 & 0.019 \\
\hline Latvia & 0.012 & 0.022 & $0.102 * * *$ & 0.013 & 0.019 & 0.019 \\
\hline Lithuania & 0.022 & 0.021 & $0.069 * * *$ & 0.015 & 0.029 & 0.019 \\
\hline Malta & $-0.223 * * *$ & 0.034 & $-0.190 * * *$ & 0.032 & $-0.050 *$ & 0.028 \\
\hline Poland & $0.050 * *$ & 0.021 & $0.071 * * *$ & 0.016 & 0.014 & 0.020 \\
\hline Slovakia & -0.029 & 0.024 & $0.069 * * *$ & 0.016 & 0.019 & 0.021 \\
\hline Slovenia & $0.037 *$ & 0.021 & $0.082 * * *$ & 0.015 & $0.052 * * *$ & 0.018 \\
\hline Bulgaria & -0.038 & 0.024 & 0.021 & 0.018 & $-0.051 * *$ & 0.022 \\
\hline Romania & $-0.108 * * *$ & 0.025 & -0.001 & 0.019 & $-0.119 * * *$ & 0.024 \\
\hline \multicolumn{7}{|l|}{ Demographics } \\
\hline female & $-0.027 * * *$ & 0.009 & $-0.017 * *$ & 0.008 & $-0.029 * * *$ & 0.009 \\
\hline married & $0.023 * *$ & 0.010 & $0.019 * *$ & 0.009 & 0.010 & 0.009 \\
\hline age & $0.004 * * *$ & 0.001 & 0.001 & 0.001 & $0.006 * * *$ & 0.001 \\
\hline squared age & $-0.000 * * *$ & 0.000 & -0.000 & 0.000 & $-0.000 * * *$ & 0.000 \\
\hline \multicolumn{7}{|c|}{ Age at completed education ( ref. $>=20$ ) } \\
\hline$<=15$ & $-0.102 * * *$ & 0.016 & $-0.059 * * *$ & 0.015 & $-0.061 * * *$ & 0.015 \\
\hline $16-19$ & -0.015 & 0.012 & $-0.024 * *$ & 0.011 & -0.016 & 0.011 \\
\hline \multicolumn{7}{|c|}{ Labour market position(ref. High-skilled white-collar) } \\
\hline unemployed & -0.016 & 0.023 & -0.032 & 0.023 & -0.007 & 0.022 \\
\hline manual worker & -0.019 & 0.018 & 0.007 & 0.016 & 0.005 & 0.016 \\
\hline low-skilled white-collar & -0.007 & 0.019 & -0.011 & 0.018 & 0.004 & 0.018 \\
\hline businessman & -0.022 & 0.026 & 0.001 & 0.023 & -0.021 & 0.025 \\
\hline out of the labour force & $-0.028 *$ & 0.017 & $-0.028 *$ & 0.015 & -0.008 & 0.016 \\
\hline $\begin{array}{l}\text { House owned } \\
\text { Trust }\end{array}$ & 0.001 & 0.010 & -0.008 & 0.010 & 0.012 & 0.010 \\
\hline national government & 0009 & 0014 & 0008 & 0012 & 0004 & 0013 \\
\hline national parliament & 0.016 & 0.014 & -0.001 & 0.013 & $0.023 *$ & 0.014 \\
\hline \multicolumn{7}{|l|}{ Ideology (ref. Left) } \\
\hline right & -0.017 & 0.013 & 0.001 & 0.012 & 0.019 & 0.012 \\
\hline centre & 0.006 & 0.012 & 0.007 & 0.010 & $0.035 * * *$ & 0.011 \\
\hline refusal/don't know & $-0.067 * * *$ & 0.015 & $-0.040 * * *$ & 0.013 & $-0.022 *$ & 0.013 \\
\hline Europeanism & $0.135 * * *$ & 0.007 & $0.117 * * *$ & 0.007 & $0.084 * * *$ & 0.007 \\
\hline EU info & $0.095 * * *$ & 0.009 & $0.066 * * *$ & 0.009 & $0.096 * * *$ & 0.009 \\
\hline Observations & 26082 & & 26082 & & 26082 & \\
\hline Prob $>$ chi 2 & 0.000 & & 0.000 & & 0.000 & \\
\hline Pseudo R2 & 0.129 & & 0.124 & & 0.078 & \\
\hline
\end{tabular}

*significant at $10 \%, * *$ significant at $5 \%, * * *$ significant at $1 \%$. 
Table A2 (cont'd). Marginal effect on the probability of consensus fo more EU integration - Control for europeanism

\begin{tabular}{|c|c|c|c|c|c|c|}
\hline \multirow[b]{2}{*}{ Variable } & \multicolumn{2}{|c|}{ Monetary policy } & \multicolumn{2}{|c|}{ Agricolture and fishery } & \multicolumn{2}{|c|}{ Regional policy } \\
\hline & coeff & $\begin{array}{c}\text { robust std } \\
\text { err }\end{array}$ & coeff & $\begin{array}{c}\text { robust std } \\
\text { err }\end{array}$ & coeff & $\begin{array}{c}\text { robust std } \\
\text { err }\end{array}$ \\
\hline \multicolumn{7}{|l|}{ Country-groups (ref. Italy) } \\
\hline Belgium & $0.106 * * *$ & 0.023 & $0.146 * * *$ & 0.024 & $0.154 * * *$ & 0.020 \\
\hline Denmark & $-0.285^{* * *}$ & 0.028 & $0.151 * * *$ & 0.025 & $0.144 * * *$ & 0.022 \\
\hline Germany & 0.018 & 0.025 & $0.134 * * *$ & 0.024 & $0.148 * * *$ & 0.021 \\
\hline Greece & $-0.287 * * *$ & 0.025 & $-0.091 * * *$ & 0.025 & $0.215^{* * *}$ & 0.018 \\
\hline Spain & -0.007 & 0.026 & 0.023 & 0.025 & $0.101 * * *$ & 0.022 \\
\hline Finland & $0.094 * * *$ & 0.024 & $-0.351 * * *$ & 0.018 & $0.041 *$ & 0.024 \\
\hline France & 0.027 & 0.025 & 0.025 & 0.025 & -0.040 & 0.024 \\
\hline Ireland & $0.201 * * *$ & 0.018 & 0.004 & 0.025 & $0.230 * * *$ & 0.017 \\
\hline Luxemburg & $0.084 * * *$ & 0.029 & -0.021 & 0.031 & $0.271 * * *$ & 0.018 \\
\hline Netherlands & 0.024 & 0.026 & $0.120 * * *$ & 0.025 & $0.261 * * *$ & 0.016 \\
\hline Austria & -0.023 & 0.027 & $-0.107 * * *$ & 0.025 & $0.074 * * *$ & 0.023 \\
\hline Portugal & -0.041 & 0.026 & $0.152 * * *$ & 0.023 & $0.248 * * *$ & 0.016 \\
\hline Sweden & $-0.326 * * *$ & 0.027 & $-0.044 *$ & 0.027 & $0.221 * * *$ & 0.019 \\
\hline UK & $-0.396 * * *$ & 0.025 & -0.024 & 0.025 & $0.090 * * *$ & 0.023 \\
\hline Cyprus & $-0.264 * * *$ & 0.032 & $0.213 * * *$ & 0.028 & $0.241 * * *$ & 0.020 \\
\hline Czech Republic & $-0.132 * * *$ & 0.027 & $-0.111 * * *$ & 0.025 & $0.044^{*}$ & 0.024 \\
\hline Estonia & $-0.262 * * *$ & 0.027 & $-0.069 * * *$ & 0.025 & $0.177 * * *$ & 0.019 \\
\hline Hungary & -0.028 & 0.026 & 0.024 & 0.025 & $0.210 * * *$ & 0.018 \\
\hline Latvia & $-0.215 * * *$ & 0.027 & -0.002 & 0.025 & $0.247 * * *$ & 0.016 \\
\hline Lithuania & $-0.185 * * *$ & 0.027 & $0.046^{*}$ & 0.025 & $0.214 * * *$ & 0.017 \\
\hline Malta & $-0.104 * * *$ & 0.033 & 0.014 & 0.033 & $0.298 * * *$ & 0.016 \\
\hline Poland & $-0.206^{* * *}$ & 0.027 & $0.066^{* * *}$ & 0.025 & $0.225 * * *$ & 0.018 \\
\hline Slovakia & $-0.087 * * *$ & 0.027 & $-0.097 * * *$ & 0.025 & $0.140 * * *$ & 0.021 \\
\hline Slovenia & $0.232 * * *$ & 0.016 & 0.010 & 0.025 & $0.130 * * *$ & 0.021 \\
\hline Bulgaria & -0.040 & 0.026 & $-0.073 * * *$ & 0.025 & $0.211 * * *$ & 0.018 \\
\hline Romania & 0.036 & 0.025 & $-0.141 * * *$ & 0.024 & $0.162 * * *$ & 0.020 \\
\hline \multicolumn{7}{|l|}{ Demographics } \\
\hline female & $-0.045 * * *$ & 0.010 & $-0.023 * *$ & 0.010 & $-0.036 * * *$ & 0.010 \\
\hline married & $0.021 *$ & 0.011 & 0.018 & 0.011 & 0.014 & 0.011 \\
\hline age & -0.002 & 0.002 & $0.007 * * *$ & 0.002 & -0.000 & 0.002 \\
\hline squared age & 0.000 & 0.000 & $-0.000 * * *$ & 0.000 & -0.000 & 0.000 \\
\hline \multicolumn{7}{|c|}{ Age at completed education (ref. $>=20$ ) } \\
\hline$<=15$ & $-0.174 * * *$ & 0.018 & $-0.087 * * *$ & 0.017 & $-0.058 * * *$ & 0.017 \\
\hline $16-19$ & $-0.062 * * *$ & 0.014 & $-0.032 * *$ & 0.013 & -0.018 & 0.013 \\
\hline \multicolumn{7}{|c|}{ Labour market position(ref. High-skilled white-collar) } \\
\hline unemployed & $-0.049 *$ & 0.029 & $-0.047 *$ & 0.027 & -0.030 & 0.027 \\
\hline manual worker & $-0.050 * *$ & 0.021 & $-0.069 * * *$ & 0.020 & $-0.035^{*}$ & 0.020 \\
\hline low-skilled white-collar & -0.022 & 0.023 & -0.035 & 0.022 & 0.004 & 0.022 \\
\hline businessman & -0.017 & 0.028 & $-0.048 *$ & 0.029 & 0.011 & 0.028 \\
\hline out of the labour force & $-0.063 * * *$ & 0.020 & $-0.060 * * *$ & 0.019 & -0.026 & 0.019 \\
\hline $\begin{array}{l}\text { House owned } \\
\text { Trust }\end{array}$ & 0.012 & 0.012 & -0.011 & 0.012 & -0.000 & 0.012 \\
\hline national government & $0.059 * * *$ & 0.016 & 0.005 & 0.016 & 0.005 & 0.015 \\
\hline national parliament & 0.005 & 0.016 & 0.013 & 0.016 & 0.008 & 0.016 \\
\hline \multicolumn{7}{|l|}{ Ideology (ref. Left) } \\
\hline right & $-0.040 * * *$ & 0.015 & $-0.045^{* * *}$ & 0.015 & $-0.036 * *$ & 0.015 \\
\hline centre & $-0.029 * *$ & 0.014 & $-0.028 * *$ & 0.013 & -0.000 & 0.013 \\
\hline refusal/don't know & $-0.064 * * *$ & 0.017 & $-0.052 * * *$ & 0.016 & $-0.058 * * *$ & 0.016 \\
\hline Europeanism & $0.171 * * *$ & 0.008 & $0.105 * * *$ & 0.007 & $0.088 * * *$ & 0.007 \\
\hline EU info & $0.084 * * *$ & 0.011 & $0.053 * * *$ & 0.011 & $0.063 * * *$ & 0.011 \\
\hline Observations & 26082 & & 26082 & & 26082 & \\
\hline Prob $>$ chi 2 & 0.000 & & 0.000 & & 0.000 & \\
\hline Pseudo R2 & 0.182 & & 0.066 & & 0.067 & \\
\hline
\end{tabular}

*significant at $10 \%, * *$ significant at $5 \%, * * *$ significant at $1 \%$. 
Table A3. IV Bivariate probit estimates (IV: 1 if the individual knows 2 or 3 economic indicators with a low error)

\begin{tabular}{|c|c|c|c|c|c|c|c|c|c|c|c|c|}
\hline & \multicolumn{4}{|c|}{ Foreign policy } & \multicolumn{4}{|c|}{ Defence } & \multicolumn{4}{|c|}{ Immigration } \\
\hline & \multicolumn{2}{|c|}{$\begin{array}{l}\text { Consensus } \\
\text { equation }\end{array}$} & \multicolumn{2}{|c|}{$\begin{array}{c}\text { Knowledge } \\
\text { equation }\end{array}$} & \multicolumn{2}{|c|}{$\begin{array}{c}\text { Consensus } \\
\text { equation }\end{array}$} & \multicolumn{2}{|c|}{$\begin{array}{c}\text { Knowledge } \\
\text { equation }\end{array}$} & \multicolumn{2}{|c|}{$\begin{array}{c}\text { Consensus } \\
\text { equation }\end{array}$} & \multicolumn{2}{|c|}{$\begin{array}{c}\text { Knowledge } \\
\text { equation }\end{array}$} \\
\hline & coeff & std err & coeff & std err & coeff & std err & coeff & std err & coeff & std err & coeff & std err \\
\hline \multicolumn{13}{|l|}{ Country-groups (ref. Italy) } \\
\hline Belgium & $-0.171 * *$ & 0.075 & $0.426 * * *$ & 0.065 & $0.265 * * *$ & 0.084 & $0.431 * * *$ & 0.066 & $0.146^{*}$ & 0.079 & $0.428 * * *$ & 0.066 \\
\hline Denmark & $-0.786^{* * *}$ & 0.075 & $0.385^{* * *} *$ & 0.071 & $-0.380 * * *$ & 0.081 & $0.386^{* * *}$ & 0.071 & $-0.368 * * *$ & 0.078 & $0.384 * * *$ & 0.071 \\
\hline Germany & $0.183 * *$ & 0.076 & $0.211 * * *$ & 0.064 & $0.329 * * *$ & 0.080 & $0.211 * * *$ & 0.064 & $0.201 * * *$ & 0.076 & $0.209 * * *$ & 0.064 \\
\hline Greece & -0.076 & 0.092 & $1.044 * * *$ & 0.068 & 0.123 & 0.100 & $1.044 * * *$ & 0.068 & $0.192 *$ & 0.099 & $1.040 * * *$ & 0.068 \\
\hline Spain & 0.040 & 0.072 & $0.240 * * *$ & 0.065 & 0.044 & 0.076 & $0.242 * * *$ & 0.065 & 0.087 & 0.074 & $0.242 * * *$ & 0.065 \\
\hline Finland & $-0.592 * * *$ & 0.073 & $0.415^{* * *} *$ & 0.070 & $-0.514 * * *$ & 0.077 & $0.417 * * *$ & 0.070 & $-0.488^{* * * *}$ & 0.074 & $0.416^{* * *}$ & 0.070 \\
\hline France & $-0.208 * * *$ & 0.068 & 0.010 & 0.065 & $0.162 * *$ & 0.073 & 0.013 & 0.065 & 0.021 & 0.069 & 0.012 & 0.065 \\
\hline Ireland & $-0.409 * * *$ & 0.072 & $0.548 * * *$ & 0.065 & $-0.616^{* * *}$ & 0.075 & $0.548 * * *$ & 0.065 & $-0.279 * * *$ & 0.074 & $0.546^{* * *}$ & 0.065 \\
\hline Luxemburg & $-0.366^{* * *}$ & 0.089 & $0.673 * * *$ & 0.081 & 0.033 & 0.098 & $0.678^{* * * *}$ & 0.081 & $-0.256^{* * *}$ & 0.094 & $0.680 * * *$ & 0.081 \\
\hline Netherlands & $-0.446 * * *$ & 0.072 & $-0.169 * *$ & 0.067 & -0.036 & 0.076 & $-0.170 * *$ & 0.067 & 0.044 & 0.073 & $-0.171^{* *}$ & 0.067 \\
\hline Austria & $-0.378 * * *$ & 0.083 & $0.798 * * * *$ & 0.069 & $-0.358 * * *$ & 0.089 & $0.794 * * *$ & 0.069 & $-0.245^{* * *}$ & 0.087 & $0.792^{* * * *}$ & 0.069 \\
\hline Portugal & $-0.428 * * *$ & 0.070 & $0.408 * * *$ & 0.065 & $-0.240 * * *$ & 0.075 & $0.408 * * *$ & 0.065 & $-0.349 * * *$ & 0.071 & $0.408 * * *$ & 0.065 \\
\hline Sweden & $-0.854 * * *$ & 0.072 & 0.026 & 0.070 & $-0.621 * * *$ & 0.074 & 0.024 & 0.070 & $-0.284 * * *$ & 0.074 & 0.022 & 0.070 \\
\hline UK & $-0.545^{* * *}$ & 0.069 & $-0.116^{*}$ & 0.066 & $-0.488^{* * *}$ & 0.070 & $-0.118^{*}$ & 0.066 & -0.105 & 0.068 & $-0.118^{*}$ & 0.066 \\
\hline Cyprus & -0.070 & 0.099 & $0.790 * * *$ & 0.083 & $0.540 * * *$ & 0.117 & $0.790 * * *$ & 0.083 & $0.252^{* *}$ & 0.107 & $0.788^{* * *}$ & 0.083 \\
\hline Czech Republic & $-0.293 * * *$ & 0.070 & 0.061 & 0.066 & $0.388 * * *$ & 0.079 & 0.063 & 0.066 & $0.302 * * *$ & 0.074 & 0.062 & 0.066 \\
\hline Estonia & $-0.175^{* *}$ & 0.070 & -0.073 & 0.066 & $0.313^{* * *}$ & 0.076 & -0.072 & 0.066 & $-0.160 * *$ & 0.069 & -0.072 & 0.066 \\
\hline Hungary & -0.023 & 0.070 & $0.182 * * *$ & 0.065 & 0.042 & 0.074 & $0.180^{* * * *}$ & 0.066 & 0.083 & 0.070 & $0.181^{* * *}$ & 0.066 \\
\hline Latvia & 0.016 & 0.069 & $0.187 * * *$ & 0.065 & $0.462 * * *$ & 0.076 & $0.187 * * *$ & 0.065 & 0.049 & 0.069 & $0.187 * * *$ & 0.065 \\
\hline Lithuania & 0.045 & 0.070 & $0.198 * * *$ & 0.065 & $0.279 * * *$ & 0.075 & $0.200 * * *$ & 0.065 & 0.081 & 0.069 & $0.200 * * *$ & 0.065 \\
\hline Malta & $-0.698 * * *$ & 0.089 & $0.715^{* * * *}$ & 0.087 & $-0.619 * * *$ & 0.095 & $0.716^{* * * *}$ & 0.087 & $-0.241^{* *}$ & 0.095 & $0.709 * * *$ & 0.087 \\
\hline Poland & 0.107 & 0.076 & $0.380^{* * *}$ & 0.065 & $0.268 * * *$ & 0.080 & $0.379 * * *$ & 0.065 & 0.003 & 0.074 & $0.379 * * *$ & 0.065 \\
\hline Slovakia & $-0.174 * *$ & 0.078 & $0.499 * * *$ & 0.068 & $0.250 * * *$ & 0.088 & $0.501 * * *$ & 0.068 & -0.003 & 0.082 & $0.500 * * *$ & 0.068 \\
\hline Slovenia & 0.040 & 0.078 & $0.462 * * *$ & 0.066 & $0.321 * * *$ & 0.085 & $0.461 * * *$ & 0.066 & 0.121 & 0.080 & $0.460 * * *$ & 0.066 \\
\hline Bulgaria & -0.066 & 0.071 & $-0.219 * * *$ & 0.067 & 0.101 & 0.074 & $-0.215^{* * *}$ & 0.067 & $-0.123^{*}$ & 0.071 & $-0.217 * * *$ & 0.066 \\
\hline Romania & $-0.212 * * *$ & 0.078 & $-0.572 * * *$ & 0.068 & 0.038 & 0.081 & $-0.568 * * *$ & 0.068 & $-0.278 * * *$ & 0.079 & $-0.569 * * *$ & 0.068 \\
\hline \multicolumn{13}{|l|}{ Demographics } \\
\hline female & -0.028 & 0.036 & $-0.288 * * *$ & 0.027 & -0.038 & 0.039 & $-0.289 * * *$ & 0.027 & -0.052 & 0.038 & $-0.287 * * *$ & 0.027 \\
\hline married & $0.065^{* *}$ & 0.031 & 0.019 & 0.029 & $0.067 * *$ & 0.033 & 0.019 & 0.029 & 0.030 & 0.031 & 0.018 & 0.029 \\
\hline age & $0.010^{* *}$ & 0.005 & $0.017 * * *$ & 0.005 & 0.003 & 0.005 & $0.017 * * *$ & 0.005 & $0.016^{* * * *}$ & 0.005 & $0.017 * * *$ & 0.005 \\
\hline squared age & $-0.000^{* *}$ & 0.000 & $-0.000 * *$ & 0.000 & -0.000 & 0.000 & $-0.000 * *$ & 0.000 & $-0.000 * * *$ & 0.000 & $-0.000^{* *}$ & 0.000 \\
\hline \multicolumn{13}{|l|}{$\begin{array}{l}\text { Age at completed education } \\
(\text { ref. }>=20)\end{array}$} \\
\hline$<=15$ & $-0.217 * * *$ & 0.058 & $-0.451 * * *$ & 0.045 & $-0.170 * * *$ & 0.060 & $-0.451 * * *$ & 0.045 & $-0.129 * *$ & 0.058 & $-0.451 * * *$ & 0.045 \\
\hline $16-19$ & -0.005 & 0.039 & $-0.226 * * *$ & 0.034 & -0.070 & 0.043 & $-0.225^{* * *}$ & 0.034 & -0.021 & 0.041 & $-0.225^{* * *}$ & 0.034 \\
\hline \multirow{2}{*}{\multicolumn{13}{|c|}{$\begin{array}{l}\text { Labour market position } \\
\text { (ref. High-skilled white-collar) }\end{array}$}} \\
\hline & & & & & & & & & & & & \\
\hline unemployed & -0.033 & 0.071 & -0.036 & 0.070 & -0.105 & 0.077 & -0.036 & 0.070 & -0.011 & 0.074 & -0.033 & 0.070 \\
\hline manual worker & -0.037 & 0.054 & -0.069 & 0.052 & 0.033 & 0.059 & -0.070 & 0.052 & 0.033 & 0.055 & -0.068 & 0.052 \\
\hline low-skilled white-collar & -0.027 & 0.060 & 0.068 & 0.058 & -0.044 & 0.065 & 0.068 & 0.058 & 0.007 & 0.062 & 0.068 & 0.057 \\
\hline businessman & -0.060 & 0.078 & 0.013 & 0.075 & 0.008 & 0.086 & 0.009 & 0.075 & -0.061 & 0.081 & 0.011 & 0.075 \\
\hline out of the labour force & -0.070 & 0.052 & -0.035 & 0.050 & $-0.094^{*}$ & 0.057 & -0.035 & 0.050 & -0.015 & 0.054 & -0.035 & 0.050 \\
\hline House owned & -0.010 & 0.033 & $0.083^{* * *} *$ & 0.031 & -0.035 & 0.036 & $0.084 * * *$ & 0.031 & 0.030 & 0.034 & $0.084 * * *$ & 0.031 \\
\hline \multicolumn{13}{|l|}{ Trust } \\
\hline national government & 0.020 & 0.044 & 0.054 & 0.040 & 0.027 & 0.046 & 0.054 & 0.040 & 0.007 & 0.045 & 0.055 & 0.040 \\
\hline national parliament & 0.026 & 0.045 & $0.137 * * *$ & 0.041 & -0.013 & 0.049 & $0.138 * * *$ & 0.041 & 0.059 & 0.047 & $0.138 * * *$ & 0.041 \\
\hline Ideology (ref. Left) & & & & & & & & & & & & \\
\hline right & -0.052 & 0.041 & 0.005 & 0.039 & 0.004 & 0.044 & 0.008 & 0.039 & 0.065 & 0.042 & 0.009 & 0.039 \\
\hline centre & 0.037 & 0.037 & $-0.076 * *$ & 0.034 & 0.034 & 0.039 & $-0.074 * *$ & 0.034 & $0.133 * * *$ & 0.038 & $-0.073 * *$ & 0.034 \\
\hline refusal/don't know & $-0.141 * * *$ & 0.048 & $-0.300 * * *$ & 0.041 & $-0.115^{* *}$ & 0.051 & $-0.300 * * *$ & 0.041 & -0.027 & 0.048 & $-0.298 * * *$ & 0.041 \\
\hline Europeanism & $0.385^{* * *}$ & 0.030 & $0.194 * * *$ & 0.019 & $0.415 * * *$ & 0.030 & $0.194 * * *$ & 0.019 & $0.253 * * *$ & 0.028 & $0.193 * * *$ & 0.019 \\
\hline EU info & $0.739 * * *$ & 0.164 & & & $0.441 * *$ & 0.190 & & & $0.677 * * *$ & 0.182 & & \\
\hline IV & & & $0.503 * * *$ & 0.033 & & & $0.502 * * *$ & 0.033 & & & $0.505 * * *$ & 0.033 \\
\hline Constant & -0.008 & 0.136 & $-0.660 * * *$ & 0.125 & $0.364 * *$ & 0.149 & $-0.662 * * *$ & 0.125 & -0.188 & 0.138 & $-0.659 * * *$ & 0.124 \\
\hline Observations & 26082 & & 26082 & & 26082 & & 26082 & & 26082 & & 26082 & \\
\hline
\end{tabular}


Table A3 (cont'd). IV Bivariate probit estimates (IV: 1 if the individual knows 2 or 3 economic indicators with a low error)

\begin{tabular}{|c|c|c|c|c|c|c|c|c|c|c|c|c|}
\hline & \multicolumn{4}{|c|}{ Monetary policy } & \multicolumn{4}{|c|}{ Agricolture and fishery } & \multicolumn{4}{|c|}{ Regional policy } \\
\hline & \multicolumn{2}{|c|}{$\begin{array}{l}\text { Consensus } \\
\text { equation }\end{array}$} & \multicolumn{2}{|c|}{$\begin{array}{c}\text { Knowledge } \\
\text { equation }\end{array}$} & \multicolumn{2}{|c|}{$\begin{array}{l}\text { Consensus } \\
\text { equation }\end{array}$} & \multicolumn{2}{|c|}{$\begin{array}{c}\text { Knowledge } \\
\text { equation }\end{array}$} & \multicolumn{2}{|c|}{$\begin{array}{l}\text { Consensus } \\
\text { equation }\end{array}$} & \multicolumn{2}{|c|}{$\begin{array}{c}\text { Knowledge } \\
\text { equation }\end{array}$} \\
\hline & coeff & std er & coeff & std err & coeff & std err & coeff & std err & coeff & std err & coeff & std err \\
\hline \multicolumn{13}{|l|}{ Country-groups (ref. Italy) } \\
\hline Belgium & $0.199 * * *$ & 0.075 & $0.422 * * *$ & 0.066 & $0.291 * * *$ & 0.068 & $0.425 * * *$ & 0.065 & $0.398 * * *$ & 0.069 & $0.430 * * *$ & 0.065 \\
\hline Denmark & $-0.796 * * *$ & 0.071 & $0.376^{* * *}$ & 0.071 & $0.303 * * *$ & 0.071 & $0.375^{* * *} *$ & 0.071 & $0.366^{* * * *}$ & 0.073 & $0.381^{* * *}$ & 0.071 \\
\hline Germany & -0.033 & 0.069 & $0.210 * * *$ & 0.064 & $0.269 * * *$ & 0.065 & $0.211 * * *$ & 0.064 & $0.372 * * *$ & 0.065 & $0.210 * * *$ & 0.064 \\
\hline Greece & $-0.931 * * *$ & 0.072 & $1.037 * * *$ & 0.068 & $-0.398 * * *$ & 0.078 & $1.052 * * *$ & 0.068 & $0.558 * * *$ & 0.090 & $1.045^{* * *}$ & 0.068 \\
\hline Spain & -0.073 & 0.069 & $0.240^{* * *}$ & 0.065 & 0.013 & 0.065 & $0.243^{* * *} *$ & 0.065 & $0.251 * * *$ & 0.065 & $0.242 * * *$ & 0.065 \\
\hline Finland & $0.165^{* *}$ & 0.076 & $0.415^{* * *}$ & 0.070 & $-1.070 * * *$ & 0.072 & $0.419 * * *$ & 0.070 & 0.072 & 0.070 & $0.420 * * *$ & 0.070 \\
\hline France & 0.056 & 0.068 & 0.012 & 0.065 & 0.048 & 0.062 & 0.011 & 0.065 & $-0.108^{*}$ & 0.062 & 0.012 & 0.065 \\
\hline Ireland & $0.511^{* * *}$ & 0.082 & $0.548^{* * * *}$ & 0.065 & -0.085 & 0.067 & $0.552 * * *$ & 0.065 & $0.658 * * *$ & 0.074 & $0.549^{* * *}$ & 0.064 \\
\hline Luxemburg & 0.083 & 0.092 & $0.669 * * *$ & 0.081 & $-0.160^{* *}$ & 0.081 & $0.680 * * *$ & 0.081 & $0.832 * * *$ & 0.094 & $0.682^{* * * *}$ & 0.081 \\
\hline Netherlands & 0.087 & 0.071 & $-0.172 * * *$ & 0.067 & $0.315^{* * * *}$ & 0.064 & $-0.170 * *$ & 0.066 & $0.829 * * *$ & 0.067 & $-0.170 * *$ & 0.067 \\
\hline Austria & $-0.253 * * *$ & 0.077 & $0.782 * * *$ & 0.069 & $-0.411 * * *$ & 0.074 & $0.799 * * *$ & 0.069 & 0.127 & 0.082 & $0.799 * * *$ & 0.069 \\
\hline Portugal & $-0.204 * * *$ & 0.069 & $0.408 * * *$ & 0.065 & $0.305^{* * *}$ & 0.069 & $0.412 * * *$ & 0.065 & $0.735 * * *$ & 0.073 & $0.410 * * *$ & 0.065 \\
\hline Sweden & $-0.819 * * *$ & 0.072 & 0.019 & 0.070 & $-0.121^{*}$ & 0.066 & 0.019 & 0.070 & $0.658 * * *$ & 0.070 & 0.024 & 0.070 \\
\hline $\mathrm{UK}$ & $-0.957 * * *$ & 0.073 & $-0.119 *$ & 0.066 & -0.035 & 0.062 & $-0.120^{*}$ & 0.066 & $0.251 * * *$ & 0.063 & $-0.118^{*}$ & 0.066 \\
\hline Cyprus & $-0.812 * * *$ & 0.083 & $0.781 * * *$ & 0.082 & $0.421 * * *$ & 0.092 & $0.794 * * *$ & 0.083 & $0.689 * * *$ & 0.097 & $0.795^{* * *}$ & 0.083 \\
\hline Czech Republic & $-0.343 * * *$ & 0.067 & 0.060 & 0.066 & $-0.286^{* * *}$ & 0.063 & 0.066 & 0.065 & $0.111^{*}$ & 0.063 & 0.064 & 0.066 \\
\hline Estonia & $-0.613^{* * *}$ & 0.070 & -0.073 & 0.066 & $-0.150^{* *}$ & 0.064 & -0.077 & 0.066 & $0.519 * * *$ & 0.064 & -0.073 & 0.066 \\
\hline Hungary & -0.105 & 0.067 & $0.180^{* * *}$ & 0.065 & 0.034 & 0.063 & $0.180 * * *$ & 0.066 & $0.610 * * *$ & 0.066 & $0.181^{* * *}$ & 0.065 \\
\hline Latvia & $-0.557 * * *$ & 0.067 & $0.182^{* * * *}$ & 0.065 & -0.029 & 0.063 & $0.186^{* * * *}$ & 0.065 & $0.763 * * *$ & 0.066 & $0.188^{* * * *}$ & 0.065 \\
\hline Lithuania & $-0.487 * * *$ & 0.067 & $0.197 * * *$ & 0.065 & 0.085 & 0.063 & $0.200 * * *$ & 0.065 & $0.627 * * *$ & 0.065 & $0.200 * * *$ & 0.065 \\
\hline Malta & $-0.412 * * *$ & 0.086 & $0.709 * * *$ & 0.086 & -0.081 & 0.087 & $0.713 * * *$ & 0.088 & $0.977 * * *$ & 0.101 & $0.715^{* * *}$ & 0.087 \\
\hline Poland & $-0.588^{* * *} *$ & 0.068 & $0.384 * * *$ & 0.066 & 0.100 & 0.066 & $0.382 * * *$ & 0.065 & $0.631 * * *$ & 0.070 & $0.382^{* * *} *$ & 0.065 \\
\hline Slovakia & $-0.345^{* * *}$ & 0.071 & $0.499 * * *$ & 0.068 & $-0.339 * * *$ & 0.068 & $0.505^{* * *} *$ & 0.068 & $0.343 * * *$ & 0.074 & $0.500^{* * *}$ & 0.068 \\
\hline Slovenia & $0.668 * * *$ & 0.086 & $0.458 * * *$ & 0.066 & -0.064 & 0.067 & $0.460 * * *$ & 0.065 & $0.318^{* * * *}$ & 0.071 & $0.463 * * *$ & 0.066 \\
\hline Bulgaria & -0.034 & 0.069 & $-0.217 * * *$ & 0.067 & $-0.125^{*}$ & 0.065 & $-0.220 * * *$ & 0.067 & $0.653 * * *$ & 0.065 & $-0.217 * * *$ & 0.066 \\
\hline Romania & $0.233^{* * *} *$ & 0.073 & $-0.567 * * *$ & 0.068 & $-0.244 * * *$ & 0.071 & $-0.568 * * *$ & 0.068 & $0.505 * * *$ & 0.070 & $-0.569 * * *$ & 0.068 \\
\hline \multicolumn{13}{|l|}{ Demographics } \\
\hline female & -0.038 & 0.033 & $-0.286 * * *$ & 0.027 & 0.005 & 0.032 & $-0.290 * * *$ & 0.027 & $-0.064 *$ & 0.034 & $-0.289 * * *$ & 0.027 \\
\hline married & 0.048 & 0.030 & 0.018 & 0.029 & 0.039 & 0.028 & 0.018 & 0.029 & 0.033 & 0.029 & 0.018 & 0.030 \\
\hline age & $-0.010^{* *}$ & 0.005 & $0.017 * * *$ & 0.005 & $0.013 * * *$ & 0.005 & $0.017 * * *$ & 0.005 & -0.002 & 0.005 & $0.017 * * *$ & 0.005 \\
\hline squared age & 0.000 & 0.000 & $-0.000 * *$ & 0.000 & $-0.000 * * *$ & 0.000 & $-0.000 * *$ & 0.000 & -0.000 & 0.000 & $-0.000 * *$ & 0.000 \\
\hline \multicolumn{13}{|l|}{$\begin{array}{l}\text { Age at completed education } \\
\text { (ref. }>=20)\end{array}$} \\
\hline$<=15$ & $-0.317 * * *$ & 0.056 & $-0.451 * * *$ & 0.045 & $-0.123 * *$ & 0.051 & $-0.449 * * *$ & 0.045 & $-0.105^{* *}$ & 0.053 & $-0.449 * * *$ & 0.045 \\
\hline $16-19$ & $-0.100 * *$ & 0.039 & $-0.223 * * *$ & 0.034 & -0.033 & 0.036 & $-0.223 * * *$ & 0.034 & -0.025 & 0.037 & $-0.224 * * *$ & 0.034 \\
\hline \multirow{2}{*}{\multicolumn{13}{|c|}{$\begin{array}{l}\text { Labour market position } \\
\text { (ref. High-skilled white-collar) }\end{array}$}} \\
\hline & & & & & & & & & & & & \\
\hline unemployed & -0.106 & 0.074 & -0.031 & 0.070 & -0.101 & 0.068 & -0.038 & 0.070 & -0.070 & 0.068 & -0.037 & 0.070 \\
\hline manual worker & $-0.099 *$ & 0.055 & -0.063 & 0.052 & $-0.147 * * *$ & 0.050 & -0.072 & 0.052 & -0.079 & 0.051 & -0.071 & 0.052 \\
\hline low-skilled white-collar & -0.065 & 0.060 & 0.074 & 0.057 & $-0.093^{*}$ & 0.055 & 0.070 & 0.058 & 0.007 & 0.056 & 0.067 & 0.058 \\
\hline businessman & -0.033 & 0.076 & 0.016 & 0.075 & -0.108 & 0.071 & 0.012 & 0.074 & 0.033 & 0.074 & 0.010 & 0.075 \\
\hline out of the labour force & $-0.144 * * *$ & 0.052 & -0.030 & 0.049 & $-0.133 * * *$ & 0.048 & -0.034 & 0.050 & -0.061 & 0.049 & -0.035 & 0.050 \\
\hline House owned & 0.010 & 0.033 & $0.084^{* * * *}$ & 0.031 & -0.044 & 0.030 & $0.084 * * *$ & 0.031 & -0.008 & 0.031 & $0.084 * * *$ & 0.031 \\
\hline \multicolumn{13}{|l|}{ Trust } \\
\hline national government & $0.142 * * *$ & 0.043 & 0.058 & 0.040 & 0.004 & 0.039 & 0.051 & 0.040 & 0.008 & 0.040 & 0.055 & 0.040 \\
\hline national parliament & -0.022 & 0.044 & $0.133^{* * *} *$ & 0.041 & 0.007 & 0.041 & $0.141^{* * *}$ & 0.041 & 0.008 & 0.042 & $0.138 * * *$ & 0.041 \\
\hline Ideology (ref. Left) & & & & & & & & & & & & \\
\hline right & $-0.101^{* *}$ & 0.040 & 0.007 & 0.039 & $-0.111 * * *$ & 0.037 & 0.008 & 0.039 & $-0.093 * *$ & 0.038 & 0.006 & 0.039 \\
\hline centre & -0.051 & 0.036 & $-0.074 * *$ & 0.034 & -0.050 & 0.034 & $-0.073^{* *}$ & 0.034 & 0.008 & 0.034 & $-0.074 * *$ & 0.034 \\
\hline refusal/don't know & $-0.080 *$ & 0.046 & $-0.301 * * *$ & 0.041 & -0.064 & 0.044 & $-0.301 * * *$ & 0.041 & $-0.119 * * *$ & 0.046 & $-0.302 * * *$ & 0.041 \\
\hline Europeanism & $0.399 * * *$ & 0.029 & $0.193 * * *$ & 0.019 & $0.222 * * *$ & 0.023 & $0.194 * * *$ & 0.019 & $0.212 * * *$ & 0.024 & $0.194 * * *$ & 0.019 \\
\hline EU info & $0.871^{* * * *}$ & 0.127 & & & $0.624 * * *$ & 0.140 & & & $0.401 * *$ & 0.167 & & \\
\hline IV & & & $0.508 * * *$ & 0.032 & & & $0.500 * * *$ & 0.033 & & & $0.502 * * *$ & 0.033 \\
\hline Constant & $0.342 * *$ & 0.135 & $-0.660 * * *$ & 0.124 & $-0.528 * * *$ & 0.123 & $-0.662 * * *$ & 0.124 & -0.157 & 0.130 & $-0.662 * * *$ & 0.125 \\
\hline Observations & 26082 & & 26082 & & 26082 & & 26082 & & 26082 & & 26082 & \\
\hline
\end{tabular}


Table A4. IV Bivariate probit estimates (IV: 1 if individual agrees that it is necessary to know the main economic figures)

\begin{tabular}{|c|c|c|c|c|c|c|c|c|c|c|c|c|}
\hline & \multicolumn{4}{|c|}{ Foreign policy } & \multicolumn{4}{|c|}{ Defence } & \multicolumn{4}{|c|}{ Immigration } \\
\hline & \multicolumn{2}{|c|}{$\begin{array}{l}\text { Consensus } \\
\text { equation }\end{array}$} & \multicolumn{2}{|c|}{$\begin{array}{c}\text { Knowledge } \\
\text { equation }\end{array}$} & \multicolumn{2}{|c|}{$\begin{array}{l}\text { Consensus } \\
\text { equation } \\
\end{array}$} & \multicolumn{2}{|c|}{$\begin{array}{c}\text { Knowledge } \\
\text { equation }\end{array}$} & \multicolumn{2}{|c|}{$\begin{array}{l}\text { Consensus } \\
\text { equation } \\
\end{array}$} & \multicolumn{2}{|c|}{$\begin{array}{c}\text { Knowledge } \\
\text { equation }\end{array}$} \\
\hline & coeff & std er & coeff & std err & coeff & std err & coeff & std err & coeff & std err & coeff & std err \\
\hline \multicolumn{13}{|l|}{ Country-groups (ref. Italy) } \\
\hline Belgium & $-0.259 * * *$ & 0.067 & $0.423 * * *$ & 0.064 & 0.081 & 0.073 & $0.433 * * *$ & 0.065 & -0.004 & 0.069 & $0.415^{* * *}$ & 0.065 \\
\hline Denmark & $-0.801 * * *$ & 0.070 & $0.493 * * *$ & 0.071 & $-0.472 * * *$ & 0.071 & $0.504 * * *$ & 0.071 & $-0.443 * * *$ & 0.070 & $0.486 * * *$ & 0.071 \\
\hline Germany & 0.067 & 0.068 & $0.390 * * *$ & 0.063 & $0.155^{* *}$ & 0.070 & $0.392 * * *$ & 0.063 & 0.062 & 0.068 & $0.384 * * *$ & 0.063 \\
\hline Greece & $-0.311^{* * *}$ & 0.071 & $1.009 * * *$ & 0.067 & $-0.229 * * *$ & 0.072 & $0.997 * * *$ & 0.068 & -0.122 & 0.076 & $0.981 * * *$ & 0.068 \\
\hline Spain & -0.028 & 0.067 & $0.252 * * *$ & 0.064 & -0.046 & 0.068 & $0.258 * * *$ & 0.065 & 0.001 & 0.067 & $0.251^{* * *} *$ & 0.065 \\
\hline Finland & $-0.630^{* * *}$ & 0.067 & $0.418^{* * *}$ & 0.069 & $-0.587 * * *$ & 0.068 & $0.420 * * *$ & 0.069 & $-0.548^{* * *}$ & 0.067 & $0.413 * * *$ & 0.069 \\
\hline France & $-0.206^{* * *}$ & 0.064 & 0.049 & 0.063 & 0.106 & 0.066 & 0.053 & 0.064 & -0.007 & 0.064 & 0.050 & 0.064 \\
\hline Ireland & $-0.494 * * *$ & 0.064 & $0.547 * * *$ & 0.064 & $-0.711^{* * *}$ & 0.063 & $0.548 * * *$ & 0.065 & $-0.399 * * *$ & 0.063 & $0.534 * * *$ & 0.064 \\
\hline Luxemburg & $-0.480^{* * *}$ & 0.077 & $0.629 * * *$ & 0.079 & $-0.192 * *$ & 0.080 & $0.614^{* * *} *$ & 0.078 & $-0.403 * * *$ & 0.082 & $0.645^{* * *}$ & 0.081 \\
\hline Netherlands & $-0.370^{* * *}$ & 0.068 & 0.001 & 0.066 & -0.004 & 0.069 & -0.000 & 0.067 & 0.061 & 0.067 & -0.006 & 0.066 \\
\hline Austria & $-0.540 * * *$ & 0.067 & $0.899 * * *$ & 0.068 & $-0.594 * * *$ & 0.066 & $0.878^{* * *}$ & 0.068 & $-0.459 * * *$ & 0.069 & $0.871^{* * *}$ & 0.068 \\
\hline Portugal & $-0.488^{* * * *}$ & 0.063 & $0.405^{* * * *}$ & 0.064 & $-0.358 * * *$ & 0.064 & $0.393 * * *$ & 0.064 & $-0.432 * * *$ & 0.063 & $0.397 * * *$ & 0.064 \\
\hline Sweden & $-0.770 * * *$ & 0.070 & $0.119^{*}$ & 0.070 & $-0.559 * * *$ & 0.069 & 0.112 & 0.071 & $-0.272 * * *$ & 0.070 & 0.103 & 0.071 \\
\hline UK & $-0.444 * * *$ & 0.065 & -0.101 & 0.065 & $-0.368^{* * * *}$ & 0.065 & -0.108 & 0.066 & -0.049 & 0.064 & $-0.112 *$ & 0.066 \\
\hline Cyprus & $-0.249^{* * *}$ & 0.085 & $0.664 * * *$ & 0.081 & $0.195 * *$ & 0.096 & $0.644 * * *$ & 0.081 & -0.008 & 0.090 & $0.642 * * *$ & 0.081 \\
\hline Czech Republic & $-0.277 * * *$ & 0.066 & 0.093 & 0.066 & $0.299 * * *$ & 0.073 & 0.095 & 0.066 & $0.231 * * *$ & 0.069 & 0.093 & 0.066 \\
\hline Estonia & $-0.127^{*}$ & 0.067 & -0.085 & 0.066 & $0.300 * * *$ & 0.069 & -0.085 & 0.065 & -0.105 & 0.065 & -0.086 & 0.065 \\
\hline Hungary & -0.059 & 0.066 & $0.148^{* *}$ & 0.065 & -0.018 & 0.067 & $0.141^{* *}$ & 0.066 & 0.024 & 0.066 & $0.142^{* *}$ & 0.065 \\
\hline Latvia & -0.024 & 0.065 & $0.170^{* * *}$ & 0.064 & $0.333 * * *$ & 0.069 & $0.154^{* *}$ & 0.064 & -0.002 & 0.065 & $0.166^{* *}$ & 0.064 \\
\hline Lithuania & -0.005 & 0.066 & $0.212 * * *$ & 0.064 & $0.174 * * *$ & 0.067 & $0.207 * * *$ & 0.064 & 0.018 & 0.064 & $0.207 * * *$ & 0.064 \\
\hline Malta & $-0.782 * * *$ & 0.081 & $0.667 * * *$ & 0.087 & $-0.757 * * *$ & 0.082 & $0.670^{* * *}$ & 0.085 & $-0.409^{* * *}$ & 0.081 & $0.640^{* * *}$ & 0.085 \\
\hline Poland & 0.001 & 0.069 & $0.388^{* * * *}$ & 0.065 & 0.096 & 0.070 & $0.373^{* * * *}$ & 0.065 & -0.107 & 0.067 & $0.379 * * *$ & 0.064 \\
\hline Slovakia & $-0.297 * * *$ & 0.068 & $0.556^{* * * *}$ & 0.066 & 0.020 & 0.073 & $0.555^{* * * *}$ & 0.067 & $-0.172 * *$ & 0.070 & $0.558 * * *$ & 0.067 \\
\hline Slovenia & -0.096 & 0.069 & $0.557 * * *$ & 0.064 & 0.090 & 0.072 & $0.549 * * *$ & 0.065 & -0.050 & 0.070 & $0.549 * * *$ & 0.065 \\
\hline Bulgaria & 0.023 & 0.066 & $-0.251 * * *$ & 0.066 & $0.197 * * *$ & 0.065 & $-0.234 * * *$ & 0.066 & -0.009 & 0.066 & $-0.245^{* * *}$ & 0.066 \\
\hline Romania & -0.028 & 0.069 & $-0.660^{* * *}$ & 0.067 & $0.254 * * *$ & 0.068 & $-0.647 * * *$ & 0.066 & -0.051 & 0.069 & $-0.650^{* * *}$ & 0.066 \\
\hline \multicolumn{13}{|l|}{ Demographics } \\
\hline female & $0.064 * *$ & 0.029 & $-0.334 * * *$ & 0.026 & $0.090 * * *$ & 0.030 & $-0.328 * * *$ & 0.027 & $0.061 * *$ & 0.030 & $-0.329 * * *$ & 0.027 \\
\hline married & $0.051^{*}$ & 0.029 & 0.016 & 0.029 & 0.047 & 0.031 & 0.015 & 0.029 & 0.018 & 0.029 & 0.011 & 0.029 \\
\hline age & 0.003 & 0.004 & $0.021 * * *$ & 0.004 & -0.005 & 0.005 & $0.021 * * *$ & 0.004 & 0.007 & 0.005 & $0.021 * * *$ & 0.004 \\
\hline squared age & -0.000 & 0.000 & $-0.000^{* * *}$ & 0.000 & 0.000 & 0.000 & $-0.000^{* * *}$ & 0.000 & $-0.000 * *$ & 0.000 & $-0.000^{* * *}$ & 0.000 \\
\hline \multicolumn{13}{|l|}{$\begin{array}{l}\text { Age at completed education } \\
\text { (ref. }>=20)\end{array}$} \\
\hline$<=15$ & -0.057 & 0.048 & $-0.494 * * *$ & 0.044 & 0.036 & 0.050 & $-0.490^{* * *}$ & 0.044 & 0.044 & 0.049 & $-0.495 * * *$ & 0.044 \\
\hline $16-19$ & $0.062 *$ & 0.035 & $-0.255^{* * *}$ & 0.034 & 0.030 & 0.038 & $-0.253^{* * *}$ & 0.034 & 0.058 & 0.036 & $-0.260^{* * * *}$ & 0.034 \\
\hline \multicolumn{13}{|l|}{ Labour market position } \\
\hline \multicolumn{13}{|c|}{ (ref. High-skilled white-collar) } \\
\hline unemployed & -0.008 & 0.067 & -0.063 & 0.068 & -0.059 & 0.072 & -0.068 & 0.069 & 0.018 & 0.068 & -0.055 & 0.069 \\
\hline manual worker & -0.000 & 0.051 & $-0.115^{* *}$ & 0.051 & 0.071 & 0.054 & $-0.117 * *$ & 0.051 & 0.067 & 0.051 & $-0.110^{* *}$ & 0.051 \\
\hline low-skilled white-collar & -0.035 & 0.056 & 0.052 & 0.056 & -0.054 & 0.060 & 0.053 & 0.056 & -0.006 & 0.058 & 0.053 & 0.056 \\
\hline businessman & -0.040 & 0.074 & -0.031 & 0.073 & 0.022 & 0.080 & -0.037 & 0.074 & -0.037 & 0.076 & -0.027 & 0.074 \\
\hline out of the labour force & -0.041 & 0.048 & -0.073 & 0.048 & -0.053 & 0.051 & $-0.081 *$ & 0.048 & 0.013 & 0.050 & -0.070 & 0.049 \\
\hline House owned & -0.033 & 0.031 & $0.089 * * *$ & 0.031 & $-0.063^{*}$ & 0.033 & $0.089 * * *$ & 0.031 & -0.003 & 0.031 & $0.090 * * *$ & 0.031 \\
\hline Trust & & & & & & & & & & & & \\
\hline national government & 0.005 & 0.042 & 0.048 & 0.040 & 0.006 & 0.043 & 0.047 & 0.041 & -0.008 & 0.041 & 0.054 & 0.040 \\
\hline national parliament & -0.015 & 0.042 & $0.135^{* * *}$ & 0.041 & -0.062 & 0.043 & $0.138 * * *$ & 0.041 & 0.005 & 0.043 & $0.136 * * *$ & 0.041 \\
\hline Ideology (ref. Left) & & & & & & & & & & & & \\
\hline right & -0.047 & 0.039 & -0.005 & 0.038 & 0.004 & 0.041 & 0.005 & 0.039 & 0.056 & 0.039 & 0.001 & 0.039 \\
\hline centre & 0.055 & 0.035 & $-0.098 * * *$ & 0.034 & $0.065^{*}$ & 0.036 & $-0.089 * * *$ & 0.034 & $0.144 * * *$ & 0.035 & $-0.091 * * *$ & 0.034 \\
\hline refusal/don't know & -0.032 & 0.042 & $-0.333 * * *$ & 0.041 & 0.032 & 0.043 & $-0.324 * * *$ & 0.041 & $0.088 * *$ & 0.042 & $-0.327 * * *$ & 0.041 \\
\hline Europeanism & $0.286^{* * *}$ & 0.027 & $0.185^{* * *}$ & 0.019 & $0.281 * * *$ & 0.028 & $0.183^{* * *}$ & 0.019 & $0.156^{* * * *}$ & 0.025 & $0.180^{* * *}$ & 0.019 \\
\hline EU info & $1.366^{* * *}$ & 0.074 & & & $1.353 * * *$ & 0.077 & & & $1.427 * * *$ & 0.083 & & \\
\hline$I V$ & & & $0.272 * * *$ & 0.027 & & & $0.285^{* * *}$ & 0.027 & & & $0.279 * * *$ & 0.027 \\
\hline Constant & $-0.214^{*}$ & 0.122 & $-0.763 * * *$ & 0.122 & 0.021 & 0.127 & $-0.766 * * *$ & 0.122 & $-0.411 * * *$ & 0.120 & $-0.754 * * *$ & 0.122 \\
\hline Observations & 26082 & & 26082 & & 26082 & & 26082 & & 26082 & & 26082 & \\
\hline
\end{tabular}


Table A4 (cont'd). IV Bivariate probit estimates (IV: 1 if individual agrees that it is necessary to know the main economic figures)

\begin{tabular}{|c|c|c|c|c|c|c|c|c|c|c|c|c|}
\hline & \multicolumn{4}{|c|}{ Monetary policy } & \multicolumn{4}{|c|}{ Agricolture and fishery } & \multicolumn{4}{|c|}{ Regional policy } \\
\hline & \multicolumn{2}{|c|}{$\begin{array}{l}\text { Consensus } \\
\text { equation }\end{array}$} & \multicolumn{2}{|c|}{$\begin{array}{l}\text { Knowledge } \\
\text { equation }\end{array}$} & \multicolumn{2}{|c|}{$\begin{array}{l}\text { Consensus } \\
\text { equation }\end{array}$} & \multicolumn{2}{|c|}{$\begin{array}{l}\text { Knowledge } \\
\text { equation }\end{array}$} & \multicolumn{2}{|c|}{$\begin{array}{l}\text { Consensus } \\
\text { equation }\end{array}$} & \multicolumn{2}{|c|}{$\begin{array}{c}\text { Knowledge } \\
\text { equation }\end{array}$} \\
\hline & coeff & std err & coeff & std err & coeff & std err & coeff & std err & coeff & std err & coeff & std err \\
\hline \multicolumn{13}{|l|}{ Country-groups (ref. Italy) } \\
\hline Belgium & $0.127 *$ & 0.072 & $0.422 * * *$ & 0.065 & $0.233 * * *$ & 0.070 & $0.427 * * *$ & 0.065 & $0.336 * * *$ & 0.080 & $0.432 * * *$ & 0.065 \\
\hline Denmark & $-0.802 * * *$ & 0.069 & $0.470 * * *$ & 0.070 & $0.243 * * *$ & 0.074 & $0.461 * * *$ & 0.070 & $0.304 * * *$ & 0.082 & $0.467 * * *$ & 0.070 \\
\hline Germany & -0.081 & 0.067 & $0.389 * * *$ & 0.063 & $0.219 * * *$ & 0.067 & $0.385 * * *$ & 0.063 & $0.319 * * *$ & 0.074 & $0.382 * * *$ & 0.063 \\
\hline Greece & $-1.006 * * *$ & 0.066 & $1.011 * * *$ & 0.067 & $-0.493 * * *$ & 0.080 & $1.036 * * *$ & 0.068 & $0.426 * * *$ & 0.120 & $1.026 * * *$ & 0.067 \\
\hline Spain & -0.101 & 0.067 & $0.254 * * *$ & 0.065 & -0.014 & 0.064 & $0.256 * * *$ & 0.065 & $0.215 * * *$ & 0.069 & $0.252 * * *$ & 0.065 \\
\hline Finland & 0.094 & 0.073 & $0.421 * * *$ & 0.069 & $-1.069 * * *$ & 0.070 & $0.427 * * *$ & 0.069 & 0.020 & 0.076 & $0.426 * * *$ & 0.069 \\
\hline France & 0.039 & 0.065 & 0.056 & 0.064 & 0.038 & 0.061 & 0.060 & 0.064 & $-0.113 *$ & 0.061 & 0.059 & 0.064 \\
\hline Ireland & $0.404 * * *$ & 0.079 & $0.547 * * *$ & 0.065 & $-0.139 * *$ & 0.068 & $0.554 * * *$ & 0.064 & $0.576 * * *$ & 0.091 & $0.548 * * *$ & 0.064 \\
\hline Luxemburg & -0.009 & 0.087 & $0.635 * * *$ & 0.080 & $-0.222 * * *$ & 0.082 & $0.656 * * *$ & 0.081 & $0.735 * * *$ & 0.113 & $0.662 * * *$ & 0.081 \\
\hline Netherlands & 0.088 & 0.068 & -0.011 & 0.066 & $0.311 * * *$ & 0.063 & -0.024 & 0.066 & $0.815 * * *$ & 0.069 & -0.020 & 0.067 \\
\hline Austria & $-0.349 * * *$ & 0.072 & $0.873 * * *$ & 0.069 & $-0.487 * * *$ & 0.074 & $0.899 * * *$ & 0.068 & 0.024 & 0.100 & $0.900 * * *$ & 0.069 \\
\hline Portugal & $-0.249 * * *$ & 0.066 & $0.404 * * *$ & 0.065 & $0.245^{* * *}$ & 0.071 & $0.418 * * *$ & 0.065 & $0.663 * * *$ & 0.089 & $0.418 * * *$ & 0.065 \\
\hline Sweden & $-0.773 * * *$ & 0.070 & 0.098 & 0.070 & $-0.124^{*}$ & 0.064 & 0.098 & 0.069 & $0.630 * * *$ & 0.073 & 0.100 & 0.069 \\
\hline UK & $-0.874 * * *$ & 0.073 & $-0.113 *$ & 0.066 & -0.018 & 0.061 & $-0.116^{*}$ & 0.065 & $0.260 * * *$ & 0.062 & $-0.112 *$ & 0.065 \\
\hline Cyprus & $-0.856 * * *$ & 0.079 & $0.665 * * *$ & 0.082 & $0.325 * * *$ & 0.098 & $0.692 * * *$ & 0.083 & $0.584 * * *$ & 0.118 & $0.698 * * *$ & 0.083 \\
\hline Czech Republic & $-0.329 * * *$ & 0.065 & 0.092 & 0.066 & $-0.281 * * *$ & 0.062 & 0.097 & 0.065 & 0.099 & 0.063 & 0.095 & 0.065 \\
\hline Estonia & $-0.556 * * *$ & 0.069 & -0.091 & 0.066 & $-0.131 * *$ & 0.064 & -0.097 & 0.066 & $0.517 * * *$ & 0.064 & -0.092 & 0.066 \\
\hline Hungary & $-0.118 *$ & 0.065 & $0.140 * *$ & 0.065 & 0.017 & 0.062 & $0.146 * *$ & 0.066 & $0.576 * * *$ & 0.071 & $0.145^{* *}$ & 0.065 \\
\hline Latvia & $-0.537 * * *$ & 0.065 & $0.153 * *$ & 0.065 & -0.042 & 0.062 & $0.161 * *$ & 0.065 & $0.724 * * *$ & 0.073 & $0.165 * *$ & 0.064 \\
\hline Lithuania & $-0.476 * * *$ & 0.065 & $0.205 * * *$ & 0.066 & 0.064 & 0.062 & $0.205 * * *$ & 0.065 & $0.590 * * *$ & 0.071 & $0.202 * * *$ & 0.065 \\
\hline Malta & $-0.475 * * *$ & 0.082 & $0.656 * * *$ & 0.087 & $-0.150 *$ & 0.088 & $0.664 * * *$ & 0.088 & $0.871 * * *$ & 0.123 & $0.667 * * *$ & 0.088 \\
\hline Poland & $-0.597 * * *$ & 0.066 & $0.389 * * *$ & 0.066 & 0.057 & 0.066 & $0.384 * * *$ & 0.065 & $0.570 * * *$ & 0.081 & $0.383 * * *$ & 0.065 \\
\hline Slovakia & $-0.399 * * *$ & 0.068 & $0.560 * * *$ & 0.068 & $-0.386 * * *$ & 0.067 & $0.569 * * *$ & 0.067 & $0.266 * * *$ & 0.087 & $0.561 * * *$ & 0.067 \\
\hline Slovenia & $0.547 * * *$ & 0.084 & $0.549 * * *$ & 0.065 & $-0.118 *$ & 0.068 & $0.547 * * *$ & 0.065 & $0.248 * * *$ & 0.083 & $0.549 * * *$ & 0.065 \\
\hline Bulgaria & 0.015 & 0.066 & $-0.256 * * *$ & 0.067 & -0.086 & 0.065 & $-0.266 * * *$ & 0.066 & $0.672 * * *$ & 0.064 & $-0.261 * * *$ & 0.066 \\
\hline Romania & $0.306 * * *$ & 0.068 & $-0.662 * * *$ & 0.067 & $-0.170 * *$ & 0.074 & $-0.656 * * *$ & 0.067 & $0.564 * * *$ & 0.072 & $-0.657 * * *$ & 0.067 \\
\hline \multicolumn{13}{|l|}{ Demographics } \\
\hline female & 0.015 & 0.031 & $-0.334 * * *$ & 0.026 & 0.044 & 0.033 & $-0.343 * * *$ & 0.026 & -0.020 & 0.041 & $-0.341 * * *$ & 0.026 \\
\hline married & 0.041 & 0.029 & 0.017 & 0.029 & 0.034 & 0.028 & 0.017 & 0.029 & 0.029 & 0.029 & 0.017 & 0.030 \\
\hline age & $-0.012 * * *$ & 0.004 & $0.021 * * *$ & 0.004 & $0.010 * *$ & 0.005 & $0.022 * * *$ & 0.004 & -0.005 & 0.005 & $0.022 * * *$ & 0.005 \\
\hline squared age & $0.000^{*}$ & 0.000 & $-0.000 * * *$ & 0.000 & $-0.000 * * *$ & 0.000 & $-0.000 * * *$ & 0.000 & 0.000 & 0.000 & $-0.000 * * *$ & 0.000 \\
\hline \multicolumn{13}{|l|}{$\begin{array}{l}\text { Age at completed education } \\
(\text { ref. }>=20)\end{array}$} \\
\hline$<=15$ & $-0.224 * * *$ & 0.055 & $-0.496 * * *$ & 0.045 & -0.060 & 0.054 & $-0.498 * * *$ & 0.044 & -0.040 & 0.064 & $-0.497 * * *$ & 0.044 \\
\hline $16-19$ & -0.057 & 0.038 & $-0.253 * * *$ & 0.034 & -0.002 & 0.037 & $-0.254 * * *$ & 0.034 & 0.007 & 0.041 & $-0.255 * * *$ & 0.034 \\
\hline \multicolumn{13}{|l|}{ Labour market position } \\
\hline \multicolumn{13}{|c|}{ (ref. High-skilled white-collar) } \\
\hline unemployed & -0.088 & 0.072 & -0.057 & 0.070 & -0.087 & 0.068 & -0.074 & 0.069 & -0.058 & 0.068 & -0.073 & 0.069 \\
\hline manual worker & -0.074 & 0.053 & $-0.106 * *$ & 0.051 & $-0.127 * *$ & 0.050 & $-0.122 * *$ & 0.051 & -0.061 & 0.052 & $-0.120 * *$ & 0.052 \\
\hline low-skilled white-collar & -0.066 & 0.059 & 0.063 & 0.056 & $-0.094 *$ & 0.054 & 0.056 & 0.057 & 0.002 & 0.056 & 0.048 & 0.057 \\
\hline businessman & -0.024 & 0.075 & -0.027 & 0.074 & -0.098 & 0.070 & -0.035 & 0.073 & 0.038 & 0.073 & -0.040 & 0.074 \\
\hline out of the labour force & $-0.123 * *$ & 0.050 & -0.065 & 0.049 & $-0.118 * *$ & 0.048 & -0.072 & 0.049 & -0.050 & 0.049 & -0.076 & 0.049 \\
\hline House owned & -0.005 & 0.032 & $0.091 * * *$ & 0.031 & $-0.052 *$ & 0.030 & $0.090 * * *$ & 0.031 & -0.019 & 0.031 & $0.090 * * *$ & 0.031 \\
\hline Trust & & & & & & & & & & & & \\
\hline national government & $0.126 * * *$ & 0.042 & 0.055 & 0.040 & -0.002 & 0.038 & 0.047 & 0.040 & 0.001 & 0.039 & 0.054 & 0.040 \\
\hline national parliament & -0.041 & 0.042 & $0.130 * * *$ & 0.041 & -0.010 & 0.040 & $0.142 * * *$ & 0.041 & -0.009 & 0.042 & $0.138 * * *$ & 0.041 \\
\hline Ideology (ref. Left) & & & & & & & & & & & & \\
\hline right & $-0.094 * *$ & 0.039 & 0.002 & 0.038 & $-0.105 * * *$ & 0.036 & 0.003 & 0.038 & $-0.090 * *$ & 0.037 & -0.001 & 0.039 \\
\hline centre & -0.034 & 0.035 & $-0.094 * * *$ & 0.034 & -0.035 & 0.033 & $-0.095 * * *$ & 0.034 & 0.020 & 0.035 & $-0.097 * * *$ & 0.034 \\
\hline refusal/don't know & -0.024 & 0.044 & $-0.338 * * *$ & 0.041 & -0.022 & 0.046 & $-0.342 * * *$ & 0.041 & -0.073 & 0.053 & $-0.342 * * *$ & 0.041 \\
\hline Europeanism & $0.343 * * *$ & 0.028 & $0.189 * * *$ & 0.019 & $0.191 * * *$ & 0.026 & $0.193 * * *$ & 0.019 & $0.182 * * *$ & 0.030 & $0.193 * * *$ & 0.019 \\
\hline EU info & $1.199 * * *$ & 0.097 & & & $0.905 * * *$ & 0.154 & & & $0.725 * * *$ & 0.234 & & \\
\hline$I V$ & & & $0.255^{* * *}$ & 0.027 & & & $0.215^{* * *}$ & 0.027 & & & $0.215^{* * *}$ & 0.028 \\
\hline Constant & 0.208 & 0.128 & $-0.758 * * *$ & 0.123 & $-0.597 * * *$ & 0.121 & $-0.734 * * *$ & 0.123 & $-0.252 *$ & 0.137 & $-0.732 * * *$ & 0.124 \\
\hline Observations & 26082 & & 26082 & & 26082 & & 26082 & & 26082 & & 26082 & \\
\hline
\end{tabular}


Table A5. Linear probability model

\begin{tabular}{|c|c|c|c|c|c|c|c|c|}
\hline \multirow[b]{2}{*}{ Variable } & \multicolumn{2}{|c|}{ EU info (first stage) } & \multicolumn{2}{|c|}{ Foreign policy } & \multicolumn{2}{|c|}{ Defence } & \multicolumn{2}{|c|}{ Immigration } \\
\hline & coeff & $\begin{array}{l}\text { robust std } \\
\text { err }\end{array}$ & coeff & $\begin{array}{l}\text { robust std } \\
\text { err }\end{array}$ & coeff & $\begin{array}{l}\text { robust std } \\
\text { err }\end{array}$ & coeff & $\begin{array}{l}\text { robust std } \\
\text { err }\end{array}$ \\
\hline \multicolumn{9}{|l|}{ Country-groups (ref. Italy) } \\
\hline Belgium & $0.152 * * *$ & 0.023 & $-0.052 * *$ & 0.022 & $0.052 * * *$ & 0.020 & 0.028 & 0.021 \\
\hline Denmark & $0.133^{* * *}$ & 0.024 & $-0.252 * * *$ & 0.025 & $-0.109 * * *$ & 0.023 & $-0.112 * * *$ & 0.024 \\
\hline Germany & $0.075^{* * *}$ & 0.023 & $0.041 * *$ & 0.021 & $0.070 * * *$ & 0.020 & $0.049 * *$ & 0.021 \\
\hline Greece & $0.349 * * *$ & 0.021 & -0.029 & 0.028 & 0.021 & 0.026 & 0.033 & 0.027 \\
\hline Spain & $0.087^{* * * *}$ & 0.023 & 0.007 & 0.021 & 0.009 & 0.020 & 0.021 & 0.021 \\
\hline Finland & $0.150^{* * *}$ & 0.024 & $-0.190 * * *$ & 0.025 & $-0.163 * * *$ & 0.024 & $-0.158 * * *$ & 0.025 \\
\hline France & 0.004 & 0.023 & $-0.066 * * *$ & 0.021 & $0.036^{*}$ & 0.019 & 0.003 & 0.021 \\
\hline Ireland & $0.195^{* * *}$ & 0.023 & $-0.129^{* * *}$ & 0.024 & $-0.198 * * *$ & 0.023 & $-0.091 * * *$ & 0.024 \\
\hline Luxemburg & $0.232 * * *$ & 0.027 & $-0.113 * * *$ & 0.028 & -0.002 & 0.025 & $-0.079 * * *$ & 0.029 \\
\hline Netherlands & $-0.058^{* *}$ & 0.024 & $-0.137 * * *$ & 0.022 & -0.008 & 0.021 & 0.014 & 0.021 \\
\hline Austria & $0.271 * * *$ & 0.023 & $-0.121 * * *$ & 0.027 & $-0.117 * * *$ & 0.026 & $-0.081 * * *$ & 0.027 \\
\hline Portugal & $0.147 * * *$ & 0.023 & $-0.136^{* * *}$ & 0.023 & $-0.074 * * *$ & 0.022 & $-0.115^{* * *}$ & 0.023 \\
\hline Sweden & 0.011 & 0.025 & $-0.289 * * *$ & 0.024 & $-0.201 * * *$ & 0.023 & $-0.086^{* * *}$ & 0.024 \\
\hline UK & $-0.043^{*}$ & 0.023 & $-0.193 * * *$ & 0.022 & $-0.177 * * *$ & 0.022 & $-0.037 *$ & 0.022 \\
\hline Cyprus & $0.276^{* * *}$ & 0.028 & -0.025 & 0.029 & $0.102^{* * *}$ & 0.024 & $0.050^{*}$ & 0.027 \\
\hline Czech Republic & 0.024 & 0.024 & $-0.085^{* * *}$ & 0.022 & $0.094 * * *$ & 0.019 & $0.082 * * *$ & 0.020 \\
\hline Estonia & -0.027 & 0.024 & $-0.044 * *$ & 0.021 & $0.077 * * *$ & 0.019 & $-0.045^{* *}$ & 0.022 \\
\hline Hungary & $0.064 * * *$ & 0.024 & -0.001 & 0.021 & 0.014 & 0.020 & 0.026 & 0.021 \\
\hline Latvia & $0.065^{* * *}$ & 0.023 & 0.010 & 0.021 & $0.111 * * *$ & 0.019 & 0.015 & 0.021 \\
\hline Lithuania & $0.071^{* * *}$ & 0.023 & 0.019 & 0.021 & $0.071 * * *$ & 0.019 & 0.025 & 0.021 \\
\hline Malta & $0.253^{* * *}$ & 0.030 & $-0.224 * * *$ & 0.031 & $-0.195 * * *$ & 0.030 & $-0.080 * * *$ & 0.029 \\
\hline Poland & $0.136^{* * *}$ & 0.023 & 0.029 & 0.021 & $0.062^{* * *}$ & 0.020 & -0.001 & 0.022 \\
\hline Slovakia & $0.181 * * *$ & 0.024 & $-0.053^{* *}$ & 0.023 & $0.049 * *$ & 0.021 & -0.008 & 0.023 \\
\hline Slovenia & $0.164 * * *$ & 0.023 & 0.004 & 0.022 & $0.067 * * *$ & 0.020 & 0.026 & 0.022 \\
\hline Bulgaria & $-0.077 * * *$ & 0.023 & -0.013 & 0.022 & 0.028 & 0.020 & $-0.038^{*}$ & 0.022 \\
\hline Romania & $-0.183 * * *$ & 0.021 & $-0.059^{* *}$ & 0.024 & 0.015 & 0.023 & $-0.090^{* * *}$ & 0.025 \\
\hline \multicolumn{9}{|l|}{ Demographics } \\
\hline female & $-0.100 * * *$ & 0.009 & -0.004 & 0.011 & -0.004 & 0.010 & -0.011 & 0.011 \\
\hline married & 0.007 & 0.010 & $0.020 * *$ & 0.009 & $0.018^{* *}$ & 0.009 & 0.008 & 0.009 \\
\hline age & $0.006^{* * *}$ & 0.002 & $0.003^{*}$ & 0.002 & 0.001 & 0.001 & $0.005^{* * *}$ & 0.002 \\
\hline squared age & $-0.000^{* *}$ & 0.000 & $-0.000^{* *}$ & 0.000 & -0.000 & 0.000 & $-0.000 * * *$ & 0.000 \\
\hline \multicolumn{9}{|l|}{$\begin{array}{l}\text { Age at completed education } \\
\text { (ref. }>=20)\end{array}$} \\
\hline$<=15$ & $-0.156^{* * *}$ & 0.015 & $-0.066^{* * * *}$ & 0.017 & $-0.047 * * *$ & 0.016 & $-0.035^{* *}$ & 0.017 \\
\hline $16-19$ & $-0.077 * * *$ & 0.012 & 0.002 & 0.011 & -0.015 & 0.011 & -0.003 & 0.011 \\
\hline \multicolumn{9}{|l|}{ Labour market position } \\
\hline \multicolumn{9}{|l|}{ (ref. High-skilled white-collar) } \\
\hline unemployed & -0.013 & 0.024 & -0.004 & 0.021 & -0.021 & 0.020 & 0.002 & 0.021 \\
\hline manual worker & -0.024 & 0.018 & -0.008 & 0.015 & 0.014 & 0.014 & 0.014 & 0.015 \\
\hline low-skilled white-collar & 0.023 & 0.020 & -0.005 & 0.016 & -0.008 & 0.015 & 0.005 & 0.017 \\
\hline businessman & 0.002 & 0.025 & -0.014 & 0.022 & 0.007 & 0.021 & -0.014 & 0.023 \\
\hline out of the labour force & -0.012 & 0.017 & -0.016 & 0.014 & -0.019 & 0.014 & 0.002 & 0.015 \\
\hline House owned & $0.029 * * *$ & 0.011 & -0.005 & 0.010 & -0.011 & 0.010 & 0.009 & 0.010 \\
\hline \multicolumn{9}{|l|}{ Trust } \\
\hline national government & 0.020 & 0.014 & 0.006 & 0.013 & 0.011 & 0.012 & 0.002 & 0.013 \\
\hline national parliament & $0.050 * * *$ & 0.014 & 0.013 & 0.014 & -0.000 & 0.013 & 0.017 & 0.014 \\
\hline \multicolumn{9}{|l|}{ Ideology (ref. Left) } \\
\hline right & 0.001 & 0.013 & -0.014 & 0.012 & 0.002 & 0.011 & 0.019 & 0.012 \\
\hline centre & $-0.027 * *$ & 0.012 & 0.010 & 0.011 & 0.010 & 0.010 & $0.039 * * *$ & 0.011 \\
\hline refusal/don't know & $-0.105 * * *$ & 0.014 & $-0.046 * * *$ & 0.015 & $-0.032 * *$ & 0.014 & -0.013 & 0.015 \\
\hline Europeanism & $0.066^{* * * *}$ & 0.006 & $0.101 * * *$ & 0.007 & $0.093 * * *$ & 0.006 & $0.065 * * *$ & 0.007 \\
\hline EU info & & & $0.244 * * *$ & 0.057 & $0.140^{* * *}$ & 0.052 & $0.227 * * *$ & 0.055 \\
\hline IV & $0.179 * * *$ & 0.012 & & & & & & \\
\hline Constant & $0.266^{* * *}$ & 0.043 & $0.531 * * *$ & 0.042 & $0.658^{* * *}$ & 0.040 & $0.483 * * *$ & 0.042 \\
\hline Observations & 26082 & & 26082 & & 26082 & & 26082 & \\
\hline R-squared & 0.165 & & 0.117 & & 0.118 & & 0.061 & \\
\hline
\end{tabular}


Table A5 (cont'd). Linear probability model

\begin{tabular}{|c|c|c|c|c|c|c|}
\hline \multirow[b]{2}{*}{ Variable } & \multicolumn{2}{|c|}{ Foreign policy } & \multicolumn{2}{|c|}{ Defence } & \multicolumn{2}{|c|}{ Immigration } \\
\hline & coeff & $\begin{array}{l}\text { robust std } \\
\text { err }\end{array}$ & coeff & $\begin{array}{l}\text { robust std } \\
\text { err }\end{array}$ & coeff & $\begin{array}{l}\text { robust std } \\
\text { err }\end{array}$ \\
\hline \multicolumn{7}{|l|}{ Country-groups (ref. Italy) } \\
\hline Belgium & 0.028 & 0.022 & $0.109 * * *$ & 0.026 & $0.145^{* * *}$ & 0.025 \\
\hline Denmark & $-0.278 * * *$ & 0.026 & $0.113 * * *$ & 0.027 & $0.134 * * *$ & 0.027 \\
\hline Germany & -0.024 & 0.023 & $0.101 * * *$ & 0.025 & 0.137 *** & 0.024 \\
\hline Greece & $-0.344 * * *$ & 0.031 & $-0.160 * * *$ & 0.034 & $0.194 * * *$ & 0.032 \\
\hline Spain & -0.034 & 0.023 & 0.005 & 0.026 & $0.095 * * *$ & 0.025 \\
\hline Finland & 0.034 & 0.024 & $-0.367^{* * *}$ & 0.025 & 0.024 & 0.027 \\
\hline France & 0.010 & 0.022 & 0.017 & 0.024 & $-0.044 *$ & 0.024 \\
\hline Ireland & $0.106^{* * *}$ & 0.023 & -0.035 & 0.027 & $0.229 * * *$ & 0.025 \\
\hline Luxemburg & -0.005 & 0.028 & $-0.065^{*}$ & 0.033 & $0.276^{* * *}$ & 0.029 \\
\hline Netherlands & 0.027 & 0.022 & $0.122 * * *$ & 0.025 & $0.292 * * *$ & 0.023 \\
\hline Austria & $-0.106^{* * *}$ & 0.029 & $-0.162 * * *$ & 0.032 & 0.041 & 0.031 \\
\hline Portugal & $-0.082 * * *$ & 0.024 & $0.115^{* * *}$ & 0.026 & $0.259^{* * *}$ & 0.025 \\
\hline Sweden & $-0.294 * * *$ & 0.025 & $-0.048^{*}$ & 0.026 & $0.240 * * *$ & 0.024 \\
\hline UK & $-0.346^{* * *}$ & 0.023 & -0.015 & 0.024 & $0.095^{* * *}$ & 0.024 \\
\hline Cyprus & $-0.295 * * *$ & 0.032 & $0.156^{* * * *}$ & 0.034 & $0.241^{* * *} *$ & 0.032 \\
\hline Czech Republic & $-0.120 * * *$ & 0.023 & $-0.112 * * *$ & 0.024 & $0.042 *$ & 0.024 \\
\hline Estonia & $-0.212 * * *$ & 0.024 & $-0.060^{* *}$ & 0.025 & $0.199^{* * *}$ & 0.024 \\
\hline Hungary & $-0.038^{*}$ & 0.022 & 0.012 & 0.025 & $0.226 * * *$ & 0.023 \\
\hline Latvia & $-0.207 * * *$ & 0.024 & -0.013 & 0.025 & $0.278 * * *$ & 0.023 \\
\hline Lithuania & $-0.170 * * *$ & 0.024 & 0.033 & 0.025 & $0.232 * * *$ & 0.023 \\
\hline Malta & $-0.157 * * *$ & 0.030 & -0.034 & 0.035 & $0.311 * * *$ & 0.029 \\
\hline Poland & $-0.207 * * *$ & 0.025 & 0.039 & 0.026 & $0.227 * * *$ & 0.024 \\
\hline Slovakia & $-0.123 * * *$ & 0.025 & $-0.135^{* * *}$ & 0.028 & $0.125^{* * *}$ & 0.027 \\
\hline Slovenia & $0.124 * * *$ & 0.022 & -0.026 & 0.027 & $0.117 * * *$ & 0.026 \\
\hline Bulgaria & -0.005 & 0.024 & $-0.048^{*}$ & 0.025 & $0.247 * * *$ & 0.024 \\
\hline Romania & $0.092 * * *$ & 0.025 & $-0.090 * * *$ & 0.027 & $0.199 * * *$ & 0.027 \\
\hline \multicolumn{7}{|l|}{ Demographics } \\
\hline female & -0.003 & 0.012 & 0.004 & 0.013 & -0.019 & 0.013 \\
\hline married & $0.017 *$ & 0.010 & 0.014 & 0.011 & 0.011 & 0.011 \\
\hline age & $-0.004 * *$ & 0.002 & $0.005^{* * *}$ & 0.002 & -0.001 & 0.002 \\
\hline squared age & $0.000^{*}$ & 0.000 & $-0.000^{* * *}$ & 0.000 & -0.000 & 0.000 \\
\hline \multicolumn{7}{|l|}{$\begin{array}{l}\text { Age at completed education } \\
(\text { ref. }>=20)\end{array}$} \\
\hline$<=15$ & $-0.096^{* * * *}$ & 0.019 & $-0.045 * *$ & 0.021 & $-0.034 *$ & 0.020 \\
\hline $16-19$ & $-0.023^{*}$ & 0.013 & -0.011 & 0.014 & -0.005 & 0.014 \\
\hline \multicolumn{7}{|l|}{ Labour market position } \\
\hline \multicolumn{7}{|l|}{ (ref. High-skilled white-collar) } \\
\hline unemployed & -0.021 & 0.024 & -0.036 & 0.026 & -0.023 & 0.025 \\
\hline manual worker & -0.020 & 0.017 & $-0.054 * * *$ & 0.019 & -0.027 & 0.018 \\
\hline low-skilled white-collar & -0.014 & 0.018 & -0.034 & 0.021 & 0.001 & 0.020 \\
\hline businessman & -0.003 & 0.024 & -0.040 & 0.027 & 0.012 & 0.026 \\
\hline out of the labour force & $-0.037 * *$ & 0.016 & $-0.049 * * *$ & 0.018 & -0.020 & 0.018 \\
\hline House owned & 0.002 & 0.011 & -0.017 & 0.012 & -0.004 & 0.011 \\
\hline \multicolumn{7}{|l|}{ Trust } \\
\hline national government & $0.047 * * *$ & 0.014 & 0.001 & 0.015 & 0.003 & 0.015 \\
\hline national parliament & -0.008 & 0.014 & 0.003 & 0.016 & 0.003 & 0.015 \\
\hline \multicolumn{7}{|l|}{ Ideology (ref. Left) } \\
\hline right & $-0.032 * *$ & 0.013 & $-0.043 * * *$ & 0.014 & $-0.033 * *$ & 0.014 \\
\hline centre & -0.014 & 0.012 & -0.018 & 0.013 & 0.004 & 0.012 \\
\hline refusal/don't know & -0.023 & 0.016 & -0.023 & 0.018 & $-0.040 * *$ & 0.017 \\
\hline Europeanism & $0.117 * * *$ & 0.008 & $0.084 * * *$ & 0.008 & $0.074 * * *$ & 0.008 \\
\hline EU info & $0.343^{* * *}$ & 0.062 & $0.252 * * *$ & 0.069 & $0.180^{* * * *}$ & 0.066 \\
\hline Constant & $0.616^{* * *}$ & 0.044 & $0.294 * * *$ & 0.049 & $0.430 * * *$ & 0.048 \\
\hline Observations & 26,082 & & 26,082 & & 26,082 & \\
\hline R-squared & 0.149 & & 0.052 & & 0.074 & \\
\hline
\end{tabular}

